\title{
12. Bougainville: Origins of the Conflict, and Debating the Future of Large-Scale Mining
}

ANTHONY J. REGAN

\section{Introduction}

The 50-year relationship between large-scale mining (LSM) and locallevel politics in Bougainville has been complex and fraught. Bougainville is the only place in the world where host community violence has resulted in the long-term closure of a large-scale mine. Bougainville Copper Ltd (BCL), a subsidiary of Conzinc RioTinto Australia (CRA), operated the huge Panguna copper and gold mine from 1972 to 1989 under a 1967 agreement with the Australian colonial administration of the then Territory of Papua and New Guinea (TPNG). The first large-scale mine in what is now Papua New Guinea (PNG), it closed in 1989, early in a violent conflict that lasted from 1988 to 1997 (Regan 1998, 2011; Braithwaite et al. 2010), and it was still closed in 2016.

Widespread perceptions exist, especially outside Bougainville, that mine closure resulted mainly from generalised Bougainvillean rejection of mining. While several main strands of causal factors have been proposedincluding ethnonationalism, culture and class (Regan 1998) and local cosmology (Kenema 2010)—most published accounts see the conflict 
originating in violent action by young mine-impacted landowners seeking permanent mine closure (e.g. Dorney 1990; Filer 1990; Connell 1991, 1992; Boege 1999; Denoon 2000; Gillespie 2009; Lasslett 2014).

Some observers (e.g. Jubilee 2014; Lasslett 2014) assert that the mine lease landowners continue to be generally opposed to any resumption of mining operations at Panguna, or that Bougainvilleans in general are opposed to large-scale mining. However, since being established in 2005 under provisions of the PNG Constitution implementing the Bougainville Peace Agreement (BPA) of August 2001, the Autonomous Bougainville Government $(\mathrm{ABG})$ has considered reopening the Panguna mine as the most realistic path to achieving the fiscal self-reliance needed for either the autonomy or possible independence contemplated by the BPA, and claims widespread (though not unanimous) community support for this approach.

This chapter examines whether the conflict was in fact a consequence of mine-impacted landowner commitment to permanent mine closure, and whether broad-based opposition to mining-by either mine-impacted landowners or Bougainvilleans more generally-was central to local politics in 2016. The chapter is in three main parts. The first outlines aspects of the context in which the conflict originated that are critical to better understanding of both its origins and some new evidence (advanced here) about several distinct Bougainvillean stakeholder groups other than young mine lease landowners, all deeply involved in the conflict origins. They occupy the 'community corner' in a rectangular model of relationships involving four main sets (or 'corners') of stakeholders, the other three being the state, mining companies, and the 'fourth estate' (Ballard and Banks 2003; also Chapter 1, this volume). The second part focuses on this new evidence, outlining the origins, concerns, roles and goals of these other 'community' stakeholders, and their relationships to one another, as well as to the state and the company. The third part discusses continuities and changes in these relationships since the conflict began, and the extent to which generalised opposition to LSM now exists. 


\section{Context of Conflict Origins}

\section{Bougainville and PNG}

Bougainville's population in 2016 is approximately 300,000 (less than 4 per cent of PNG's total population). Its 9,438 square kilometres is roughly 2 per cent of PNG's total land area. Pre-colonial Bougainvilleans were organised mainly around tiny stateless societies involving great diversity in language, ${ }^{1}$ culture (Ogan 2005), and identities (Regan 2005a). Despite major social and economic changes since colonial 'rule' began in the late nineteenth century, the most significant social groups today continue to be nuclear and extended families, the localised clan-based landowning lineages to which those families belong (typically containing 50-150 members), and flexible groupings of such lineages.

While under nominal German colonial control from 1884 to 1915 , the first administrative centre was only established in 1905, and Australia took control from 1914 to 1975 . Under colonialism, interactions with people from elsewhere in PNG contributed to a pan-Bougainvillean identity, with the dark skin colour of most Bougainvilleans as the primary marker (Nash and Ogan 1990). Identity politicisation occurred after World War II, when:

because of the natural affluence of their village life and the coverage of the [Bougainville] district by Christian missions (mainly Catholic and non-Australian), the administration neglected to play a conspicuous role in development almost until copper was discovered. Bougainville was known as the 'Cinderella' district not because it was poor but because it was ostensibly neglected (Griffin et al. 1979: 150).

Identity politicisation was intensified by resentment of colonial racism (Ogan 1965, 1971a, 1972) and by development of the mine, which was seen as something imposed to benefit the rest of PNG with little regard to detrimental impacts on Bougainville itself.

A major manifestation of change since 1905 has been the expanding range of groups or organisations to which Bougainvilleans belong or relate (churches, women's groups, local governments, economic enterprises, political parties, etc.). Nevertheless, the autonomy long enjoyed by local

1 There were 25 languages and a comparable number of sub-languages or dialects (Tryon 2005). 
lineages and other pre-colonial social groupings remains the default position for Bougainvillean understandings of how to relate to these new social phenomena. This expectation of autonomy helps to explain the extent to which the diverse groups involved in the origins of the conflict expected autonomy from one another, as do groups involved in contemporary debates on the future of mining.

For most rural Bougainvilleans, PNG remains remote (Tanis 2005: 468). This was even more so in 1963, when PNG-wide politics first developed around the election of TPNG's first representative legislature, which included just one Bougainvillean representative. Concerns about national representation of Bougainville probably had little effect on voters in the 1963 and 1968 elections (Ogan 1965, 1971a; Anis et al. 1976). However, rapid changes associated with development of the mine led to much wider understanding of such matters in the 1972 elections, contributing to the election of a young Catholic priest from Buin, John Momis, a critic of the mine and the administration, who continues to be a key political figure in Bougainville.

Growing agitation for a special political and financial status saw an interim Bougainville Provincial Government established in 1974 (Ghai and Regan 1992: 55-9), and disputes over its mine revenue share precipitated Bougainville's attempted secession from PNG on 1 September 1975, just before PNG's Independence Day. The crisis was resolved in mid1976, when the PNG Government agreed to constitutional provision for provincial government and guaranteed that the new North Solomons Provincial Government (NSPG) ${ }^{2}$ would receive all of the royalties from the mine aside from the 5 per cent already payable to some of the Panguna mine lease landowners (Bedford and Mamak 1977). Many Bougainvilleans concluded that only intense confrontation with PNG brought results, and that the little understood process of secession (Ogan 1990: 36) and status of independence would remedy many problems.

Following the 1976 agreement to end attempted secession, Bougainvilleans had high expectations of the NSPG. In 1977, John Momis became the PNG minister responsible for the new provincial government system established under the agreement. Strong support for autonomy of the NSPG was now expected from the centre, and these expectations were reinforced by establishment of the Momis-led Melanesian Alliance (MA)

2 See Regan (2005b) on reasons for use of the different names, 'North Solomons' and 'Bougainville'. 
party in 1980. The MA soon dominated both NSPG politics (especially from 1984) and Bougainville's four seats in the PNG Parliament. But neither Momis nor his party had a significant impact on PNG policy towards Bougainville. By the mid-1980s, the NSPG's lack of expected powers over areas of growing concern, such as mining, land and internal migration, was a source of widespread disappointment (Ghai and Regan 2000, 2006). For many, the failure to pursue secession appeared to have been a mistake.

\section{Mine Revenue Distribution and Landowner Compensation}

The social, economic and environmental impacts of mine exploration and feasibility work (1963-69), construction (1969-72) and operation (1972-89) were especially shocking for mine lease landowners but also shocked most other Bougainvilleans on many levels. The 10,000-strong construction workforce-mostly recruited from elsewhere in PNGwas more than 10 per cent of Bougainville's total population at the time. From 1972, the permanent workforce was around 3,500, about 80 per cent of them Papua New Guineans, less than a third of whom were Bougainvilleans (Quodling 1991: 37).

The limited mine employment opportunities were resented, but the far more limited mine revenue share received, not only by mine lease landowners but also by Bougainville as a whole, was of even greater concern for multiple groups involved in the origins of the conflict. Between 1972 and 1989 the four main recipients of mine-derived revenue were:

- mine lease landowners, receiving 5 per cent of royalties, occupation fees and various forms of compensation;

- from 1977 the NSPG, receiving 95 per cent of royalties, some local taxes, and other limited payments;

- the PNG Government, receiving company tax, other tax receipts, and dividends in its capacity as the largest minority (19.1 per cent) shareholder in BCL; and

- private investors (including CRA as the majority BCL shareholder) receiving dividends (see Table 12.1). 
Table 12.1 Distribution of Panguna cash revenues, 1972-89.

\begin{tabular}{|l|r|r|}
\hline Stakeholder & Kina (million) & $\%$ \\
\hline PNG Government & 1,078 & 61.46 \\
\hline Private investors & 577 & 32.90 \\
\hline North Solomons Provincial Government & 75 & 4.28 \\
\hline Local landowners & 24 & 1.37 \\
\hline Total & $\mathbf{1 , 7 5 4}$ & $\mathbf{1 0 0 . 0 0}$ \\
\hline
\end{tabular}

Source: Author's table, based on data from Quodling (1991: 34).

The landowner revenue share was a tiny percentage of total revenues, was distributed in ways that were poorly understood by most people, and involved significant sources of inequality.

Development of the mine entailed a number of leases, the main ones being state leases to BCL of land held under customary arrangements by small matrilineages from six different language groups-Torau, Nasioi, Eivo, Nagovisi, Baitsi and Piva-the majority being Nasioi speakers. BCL's three main leases, ${ }^{3}$ together covering 13,047 hectares, comprised a 'special mining lease' (SML) for the open-cut pit, processing plant and associated facilities; a 'port-mine access road lease' (PMARL) over land from the east coast to the mine; and a 'tailings lease' over the Kawerong-Jaba river system, covering land from the mine to the west coast. After BCL's land needs were finalised in mid-1969, colonial patrol officers (kiaps) spent much of the next three years walking every part of the lease areas with community members, demarcating the boundaries of the 829 land parcels or 'blocks', ${ }^{4}$ of which there were 509 in the SML, 62 in the PMARL and 258 in the tailings lease.

Members of occupying lineages were henceforth generally referred to as mine lease 'landowners', though most had hazy ideas of what the term meant (Tanis 2005). The administration and BCL were just as hazy about precise identification of landowning lineage membership, as nothing akin to what is now known as social mapping was ever done to identify the members of the lineages involved. In part this was because of lack of precedents (this being PNG's first large-scale mine), but also because of pressure from CRA to finalise land demarcation as quickly as possible

3 There were also numerous much smaller leases (McNee 2015).

4 Origins of the term 'block' are discussed in McNee (2015: 200-8); see also AGA (1989: 31) and Filer (1990: 11-12). 
from mid-1969, resulting in the kiaps involved having no time to compile the group genealogies that they were trained to use whenever acquiring land for the state.

From 1966 until about 1970, many mine lease area lineage members opposed both exploration and mining (Bedford and Mamak 1977; Denoon 2000; Vernon 2005; Brown 2014). Overt opposition ended after the deployment of significant colonial administration resources (kiaps and police), when 'protests and expectations became apparently more futile' (Connell 1990: 28), and after agreement was reached on four main types of compensation payable to affected landowners, in addition to the 5 per cent share of royalties already payable to SML landowners (Bedford and Mamak 1977). Compensation involved:

- $\quad$ payments for damage to land, buildings and crops, most being made during the exploration and construction phases;

- occupation fees paid at a uniform rate per hectare to the 'customary heads' of lineages owning the 829 blocks in the expectation that they would distribute the funds they received to other lineage members in accordance with custom;

- new houses for people whose land in the SML and tailings lease was actually destroyed, with some relocation costs; and

- compensation for fish populations in mine-impacted creeks and rivers, which was paid to customary right holders (known as 'fish-owners').

Acceptance of such payments did not entail landowner acquiescence. When compensation rates were initially determined, the recipients had no concept of the scale of the future impacts. As the enormity of the impacts became evident, community unhappiness grew.

In public hearings between 1969 and 1974, the PNG Land Titles Commission (LTC) ${ }^{5}$ determined the 'customary heads ${ }^{6}$ of the landowning lineages and the boundaries of each of the 829 blocks, relying heavily on the prior work of the kiaps. Bedford and Mamak (1977: 71) found that 'approximately 440 registered owners ['customary heads'] ... represent at least 2,000 men, women and children'. 'The number of 'customary heads'

5 The files from these hearings are held by the LTC office in Port Moresby. I am grateful to the Chief Land Titles Commissioner, Benedict Batata, for locating and providing access to these records. 6 While 'customary head' was the term used almost universally by the LTC, 'the terms title holder and owners do appear' in the relevant LTC files (McNee 2015: 206).

7 The actual number of people is not known, but was probably over 4,000. 
was so much smaller than the number of blocks because a person could be a member and a 'customary head' of lineages occupying more than one block. Amounts paid to 'customary heads' varied immensely, depending on the number and size of the blocks involved (see Table 12.2). The largest blocks were in coastal areas of the tailings lease, the most sparsely populated area within the three main leases, where the single largest block was 960 hectares, 27 were larger than 100 hectares, and almost two thirds of 258 blocks were over 10 hectares. By contrast, in the SML and the PMARL, no block was larger than 100 hectares, and almost three quarters were less than 10 hectares. More than half the total occupation fees for all three leases went to just 114 'customary heads' from 14 villages in the tailings lease. One quarter went to the people of just one relocated village (Bedford and Mamak 1977: 69-76).

Table 12.2 Numbers of blocks in the three main BCL leases.

\begin{tabular}{|l|r|r|r|}
\hline Area & SML & PMARL & Tailings Lease \\
\hline$<1$ hectare & 96 & 12 & 16 \\
\hline $1-10$ hectares & 297 & 40 & 77 \\
\hline $10-100$ hectares & 116 & 10 & 138 \\
\hline $100-200$ hectares & 0 & 0 & 20 \\
\hline $200-300$ hectares & 0 & 0 & 3 \\
\hline$>300$ hectares & 0 & 0 & 4 \\
\hline Total Blocks & $\mathbf{5 0 9}$ & $\mathbf{6 2}$ & $\mathbf{2 5 8}$ \\
\hline
\end{tabular}

Sources: PNG Land Titles Commission files and BCL compensation and occupation fee payment records.

Under the last compensation agreement between BCL and landowner representatives, signed in March 1986, K604,440.57 in occupation fees and bush compensation was payable annually to 'customary heads' from 1986 to 1989 . From this total, K195,738.01 would go to the SML, K20,741.15 to the PMARL, and K487,961.41 to the tailings lease. If this money were distributed equally between the 829 blocks, it would mean an annual payment of K729 per block. An additional amount of K259,687 was to be paid each year to the 'fish-owners', and if this money were distributed equally between their 1,200 'group leaders', then each one would receive an annual payment of K216.40. However, for reasons already discussed, there were great disparities in the amounts received by the 'customary heads' or 'group leaders', and hence in the amounts available to be redistributed to lineage or group members. 
Problems arising from the totality of the compensation arrangements undoubtedly contributed to the origins of the conflict. There were at least five issues that contributed to landowners having limited understanding of the arrangements:

- Most lineage members had little exposure to ideas of land ownership that would have made sense of the designation of a particular lineage as the owner of a block, or a particular person as its 'customary head' (Filer 2005; Tanis 2005; Kenema 2010).

- Expectations that 'customary heads' would distribute occupation fees and compensation payments to lineage members in accordance with 'custom' ignored the fact that neither the title nor the role of these individuals was customary, and there were no customary norms about distributing cash compensation paid for land that was used for previously unknown purposes such as industrial mining (Filer 1990). ${ }^{8}$

- The lack of 'social mapping' to identify the social and leadership structures or membership of 'landowning' lineages meant that there was no certainty about who might be entitled to a share of the payment for each block, leaving 'customary heads' with much discretion in distribution, some being renowned for favouritism to particular relatives while largely ignoring others with similar standing in the lineage.

- Most lineage members had limited knowledge of either English or Tok Pisin, which limited their understanding of the LTC process, which made it possible for people to be designated as 'customary heads' when this designation might otherwise be contested.

- When compensation rates were determined, few lineage members had any idea of the scale of mine impacts. What initially seemed reasonable was often questioned by the time the mine was operating.

These sources of limited understanding amplified the impacts of an additional set of five problems related to actual or perceived inequality in compensation arrangements:

- The payment of uniform rates per hectare took no account of the scale of impacts in different locations. Some communities suffered far more than others due to land destruction (by the pit or the tailings) and

8 This may help to explain why the term 'customary head' was soon almost universally replaced by the term 'title-holder' in virtually all contexts except LTC documentation. 
village relocation. ${ }^{9}$ Small block size and higher population densities in the SML and upper parts of the tailings lease meant that small amounts were distributed to many more people than in lower parts of the tailings lease.

- Secondary land rights were ignored, although they could be significant, and lack of compensation for their loss caused resentment, especially where land was destroyed.

- Some 'customary heads' treated payments as being made to them as individuals, with no need for distribution to other lineage members or other persons who believed they had rights to the block in question. This was partly a consequence of 'customary heads' becoming generally known as 'title-holders', which led some to assume they had individual ownership rights. However, individuals rather than customary groups could sometimes have semi-exclusive rights to particular blocks under custom (Ogan 1971b; Mitchell 1976: 22), and most 'customary heads' registered for the largest blocks in the tailings lease fell into this category.

- No account was taken of rapid population growth and the numbers of young people reaching adulthood, resulting in gradual but inexorable diminution in the size of average available payments, with little reaching most young adults. Combined with other problems, the extent of the discretion of 'customary heads' caused seriously unequal intergenerational distribution.

- The limited compensation rights of communities outside but adjacent to BCL leases, whose members often experienced significant mining impacts, generated a particular sense of injustice.

Impacts and resentment were greatest amongst SML communities, due to the significant proportions of people relocated, the small average block size and high population density, proximity of the mine pit and its noise and dust, and the presence of many outsiders on their land. Many SML

9 Relocation housing was neither of high standard nor maintained by BCL, and lacked provision for newly married couples, causing significant overcrowding and cultural stresses through the breach of post-marriage residence rules. Relocated SML villages lost all or most of their gardening land. Residents of villages near the mouth of the Jaba River were relocated to land over which they had few rights, resulting in ongoing tensions with the original owners. Such problems continue today, exacerbated by the absence of compensation payments since 1990, and by rapid population growth in both settler and host communities (personal communications, Albert Magoi, Ben Paula and Bernadine Kirra, July 2011). 
community members had the mine or its facilities in plain sight, and access to all SML villages and hamlets was by means of a road through the lease.

By the late 1970s, landowner concerns grew, and BCL's slow responses caused anger. In 1979, landowners looted the Panguna supermarket, and their first representative body, the Panguna Landowners Association (PLA), was established. In 1980, landowners marched on BCL's Panguna offices and erected roadblocks, causing temporary mine closure. Despite pressure from PNG's police minister to deploy police mobile squads to clear the roadblocks, Ila Geno, then commander of the New Guinea Islands police region (including Bougainville and four other provinces) refused to do so. Instead he travelled from his base in East New Britain Province to work with the NSPG to negotiate with landowner leaders, including Francis Ona, to remove the roadblock (personal communication, Ila Geno, July 2014). These events contributed to pressure for a new compensation agreement between BCL and the PLA. Signed later in 1980, it provided for higher compensation rates, indexing of occupation fee rates, regular reviews, and a new compensation category called 'social inconvenience compensation' (SIC). The SIC was to be paid into a new landowner-controlled entity, the Road Mine Tailings Lease Trust Fund (RMTLTF), which was required to utilise the income for landowner benefit (Okole 1990; Oliver 1991: 153, 203-4; Connell 1992: 38-43; Griffin and Togolo 1997: 376). Under the subsequent 1986 Agreement, the annual SIC payment was K393,838.69.

Hopes that the 1980 Agreement would improve the landowner situation were not met. The new landowner bodies, the PLA and RMTLTF, became sources of new problems. Unresolved concerns about unequal impacts and compensation were exacerbated by control of both bodies by a few 'customary heads', all older generation males. Emerging younger generation leaders complained that the PLA failed to pursue landowner concerns with sufficient vigour.

In the 1980s, younger generation leaders from SML communities, including Perpetua Serero and Francis Ona, had particular reasons for intense resentment due to issues of the kind previously outlined. Amongst other things, Ona and Serero were from a village close to the mine pit, in an area with relatively high population density, with land rights derived from the male line rather than the usually more significant female line 
(Ogan 1990: 37). More important, what rights they had were to several blocks where an uncle, Matthew Kove, was registered as the 'customary head', and ignored their claims to shares in land compensation. ${ }^{10}$

The RMTLTF board initially made low-interest loans to landowners, but limited funds soon saw complaints of inequitable distribution. In 1983, Severinus Ampaoi, a landowner leader and senior BCL employee, became chairman of the board. Substantial bad debts were written off and a stricter financial regime introduced, with an end to the distribution of immediate benefits to landowners. An accumulation strategy was adopted to provide a basis for long-term benefit distribution. ${ }^{11}$ Shares were purchased in Bougainville Development Corporation (BDC), the successful business arm of the NSPG, in circumstances of great controversy. Funds were also invested in urban real estate and two plantations. Close cooperation with the BDC board contributed to perceptions that the RMTLTF board was part of a remote, wealthy Bougainvillean elite. There were mounting accusations of mismanagement, of directors 'eating' the money, of a lack of spending on landowner social amenities, of irregular board meetings, of a lack of information and of the board being dominated by 'outsiders' (Connell 1992: 42-5; Thompson and MacWilliam 1992: 36; see also Okole 1990; Turner 1990; Oliver 1991: 203-4). The central problem involved perceptions that a compensation category intended to benefit landowners in general now mainly benefited older men who were already wealthy and were too close to BCL.

\section{The Bougainvillean Elite}

A small Bougainvillean elite, mainly involved in copra production, first emerged in the 1950s (MacWilliam 2005), growing from the 1960 s as smallholder cocoa production expanded. From the 1970s, burgeoning cocoa production contributed to land pressures and growing economic inequality (Mitchell 1976, 1982; Connell 1978, 1988; Tanis 2005: 456-9; MacWilliam 2013). Unequal compensation from the mine created another wealthy group (Tanis 2005: 455), as did establishment

10 Dorney (1990: 123) and Jubilee Australia (2014: 20) suggest that designation of males as 'customary heads' was contrary to custom. In fact, well over half of those so designated were females, and as males are members of the lineages recognised as occupying land, and may well also have individual rights to land under custom, there is no reason in principle why males should not have this designation.

11 The mine was then expected to close around the year 2000. 
of mine-associated businesses. Growing inequality fuelled resentment in societies until recently highly egalitarian (Ogan 1990: 36; Regan 1998: 271-2, 274-6).

A major source of disquiet was the BDC board's response to a 1985 request from the newly elected, MA-dominated NSPG for most board members to resign. The board members included the recently ousted premier, Leo Hannett, and others close to him. The board response was to issue new shares, diluting NSPG's 57 per cent equity to 29 per cent. Moreover, without any offer being made to the majority shareholder, the new shares were allotted to six corporate entities and an individual. The new shareholders included the family companies of board members, the RMTLTF, BCL's superannuation fund, and the 'Severinus Ampaoi Group'. While BDC shares had previously been worth K9, the new shares were priced at K1.30, which entailed a major loss for the NSPG but a windfall gain for the new shareholders (Griffin and Togolo 1997: 375). The NSPG challenged this action in widely publicised National and Supreme Court proceedings. Although eruption of the conflict in late 1988 meant the case was never finally determined, a 1988 Supreme Court ruling 12 held that the NSPG 'had, prima facie, good grounds for challenging the share issue' (see Griffin and Togolo 1997: 374).

A widespread perception developed of joint action between BDC and the RMTLTF to enrich board members at the expense of other Bougainvilleans (Thompson and MacWilliam 1992; Wesley-Smith 1992a). The involvement of BCL in the BDC share issue (through its superannuation fund) and allocation of BDC shares to the RMTLTF and the Ampaoi family completed the picture. Many people, particularly MA supporters, saw the share issue as the culmination of BDC's general performance, allegedly hijacking lucrative business opportunities and blocking local Bougainvillean small and medium-sized business participation in spin-offs from the mine (Griffin and Togolo 1997: 374). As a result, $\mathrm{BDC}$ was 'seen in the village as a private business benefitting a few individuals', becoming 'an object of exactly the same kind of anger and resentment' as the PLA and RMTLTF (Tanis 2005: 466). 'In the popular mind, grievances against BDC, the directors of the landowners' trust fund [RMTLTF] and BCL (which had been patron of and provided advice to BDC) became intertwined' (Griffin and Togolo 1997: 375). 
As we shall see, the MA's trenchant mid-1980s critique of Bougainvillean 'big business' was to be echoed strongly in 1988 statements and demands by Francis Ona and the 'new' PLA.

\section{Population Growth and Youth Unemployment}

Bougainville's population grew rapidly after World War II, from about 41,000 in 1950 (Nelson 2005: 196) to about 73,000 in 1966 (Laracy 2005: 125), about 109,000 in 1980 (Oliver 1991: 160-1), and about 150,000 in 1986. This means an annual growth rate of between 3.4 and 3.5 per cent (NSPG 1986a; Oliver 1991: 161). Much of Bougainville's land is unsuitable for intensive agriculture (Oliver 1991: 10-12). In the 1980s, more than 80 per cent of Bougainvilleans were concentrated in the limited areas of accessible arable land, heavily reliant on subsistence farming, with some cash crop cultivation. Both population growth and cocoa expansion from the 1960s depleted forest and other natural resources in proximity to the most densely populated areas and intensified local land shortages (Connell 1978, 1988; Mitchell 1982; Tyler 1988; Lummani 2005; MacWilliam 2013: 144-9, 184-6, 193). Economic inequality grew in many relatively densely populated parts of central and southwest Bougainville, including the Nasioi, Siwai, Nagovisi and Buin language areas (Mitchell 1982: 8; Connell 1988: 84-5; Tanis 2005: 456-7). ${ }^{13}$

In the mid-1980s, more than 47,000 Bougainvilleans were aged from twelve to twenty-five years and classified as 'youth'; 68 per cent of them were living in rural villages, 9 per cent in other rural settlements, and 23 per cent in urban areas (NSPG 1986a). Twenty-five per cent of these young people had no formal education, 18 per cent had some primary schooling up to grade 5 , and 39 per cent only to grade 6 . Only 18 per cent had completed any high school grade. Further training or education opportunities were limited, as was wage employment. Only 19 per cent of young people were in formal employment, another third being involved in agriculture. Bougainvilleans enjoyed little preference in mine-related business and employment opportunities. Young males with little or no

13 Pre-colonial migration into parts of the Siwai area, which had been caused by localised conflict, resulted in the presence of people who still had limited rights to land in the 1980s (personal communications, Michael Kouro 1999, Marie Tyler 2011, and Jonathan Ngati 2003). Some of them rented land for subsistence gardens and cash crops (Tyler 1988: 18), while others emigrated to seek opportunities elsewhere. 
formal education faced particular problems, many having little access to land for cash cropping (Regan 1998: 274-6). Those with some education, but not enough to gain employment, often had unrealistic expectations and experienced difficulty fitting into village life (NSPG 1986a: 28-9).

\section{Resentment of Outsiders}

An unknown but significant number of residents in pre-conflict Bougainville (perhaps 20,000 out of a total population of about 150,000) originated from elsewhere in PNG. Several thousand worked as labourers on Bougainville's mainly foreign-owned copra and cocoa plantations (Lummani 2005: 253), often staying on in Bougainville when their contracts expired. Similarly, some of the 10,000-strong mine construction workforce stayed on after construction ended (Mamak et al. 1974: 11-12). Others came later, attracted by Bougainville's economic opportunities.

In the closely linked urban areas largely servicing the mine-Arawa, Panguna, Kieta and Toniva-and in 'squatter settlements' in both nearby rural areas and parts of the mine lease areas (Tanis 2005: 467), the numbers of 'outsiders' grew rapidly from the 1970s. An April 1988 household survey (NSPG 1988a) showed a population of 17,314 (many from elsewhere in PNG) in 'formal' housing areas of Arawa and nearby urban areas, and 4,259 (most from elsewhere in PNG) in nearby 'informal settlements'. Connell (1990: 48-9) reports a population of about 3,500 for Panguna, and the proportion of Bougainvilleans in the towns as being 'barely more than a third of the total'. A 1986 report discussed the many problems with informal settlements that 'caused ... conflict with the local people which in turn puts greater pressure on the Government to take action' (NSPG 1986b).

Many Bougainvilleans blamed 'outsider' squatters for increased crime and land disputes, and for taking over the economy, including formal sector jobs, local fruit and vegetable markets, and small-scale mine-related and other businesses (NSPG 1986b, 1988a; Tanis 2005: 466). In the 1988 NSPG election, a non-Bougainvillean was elected to the provincial assembly by votes from the growing concentration of non-Bougainvilleans. In his home area of Nagovisi, James Tanis (2005: 466) reports worries that this showed outsiders 'were taking over the government, and would control power, protect the squatter settlements and threaten customary land ownership'. 
In March 1988, in response to such concerns, the NSPG announced a joint operation with the police force, known as Operation Mekim Save ('Make Them Take Notice'). However, this did not lead to the expected expulsion of unemployed non-Bougainvilleans and destruction of squatter settlements. Instead, an NSPG report talked of PNG constitutional rights protecting outsiders (NSPG 1988a). Tanis describes how frustrated villagers felt that the right to freedom of movement under the PNG Constitution:

was now being exercised by outsiders at the expense of the rights of Bougainvilleans to the freedom to enjoy their customary land ... Whereas the category of 'threatened' landowners was once restricted to those living in mine lease areas, increasingly there was a sense in which all Bougainvillean landowners felt threatened by, and had grievances against, outsiders (Tanis 2005: 466-7).

\section{Church Allegiances}

The three Christian churches with earliest access to Bougainville gained significant influence there. The Catholics arrived first in 1901, followed by the Methodists in 1917 and Seventh Day Adventists in 1924 (Oliver 1991: 58-64). By the 1960s, the Catholics had 'converted up to 80 per cent of the people ... with the Methodists - later the UnitingChurch 15 per cent and the Seventh Day Adventists five per cent' (Griffin 1995: 10). All three main churches combined spiritual 'formation' with provision of health and education services. An almost complete lack of government services in most areas of Bougainville contributed to commonly expressed grievances about colonial neglect. ${ }^{14}$ Catholic Church activity was especially pervasive: an amazing 30 stations operated across Bougainville in 1966 (roughly one per 2,000 Catholics), most with associated schools and clinics (Laracy 2005: 125; see also Oliver 1991: 58-68).

Catholic education was partly directed to training local priests in an elite seminary system. Though most of the trainees never became priests, they constituted a linked and articulate elite, familiar with Catholic social teachings. While the Methodist and Seventh Day Adventist churches were generally supportive of the colonial administration, the Catholics were more independent. From the early 1960s, they sponsored economic

14 There were no government schools at all until the 1950s. 
development activities, initially largely in reaction to the grievances of the Buka-based Hahalis Welfare Society, which accused the church of neglecting the material well-being of its adherents (Rimoldi and Rimoldi 1992; Laracy 2005: 131). Some priests publicly criticised the administration's treatment of 'natives' in relation to forestry and other projects (Fingleton 1970; Laracy 2005: 131).

In a series of press releases, church publications and a strong letter to the colonial administrator, all in 1966, the head of the Catholic Church in Bougainville, Bishop Lemay, criticised the administration's actions in the early stages of mine exploration, describing colonial mining law as 'unsuitable and as contravening native land customs and traditions' (Lemay 1966, cited in Laracy 1999: 583). This stand caused considerable concern in the colonial administration (Downs 1980: 350-2; Laracy 2005)..$^{15}$

In 1975, Lemay's successor, Gregory Singkai, the first Bougainvillean bishop, supported secession, saying 'we realised that most of the people involved in the independence movement ... are Catholic and we decided it is better for us to be with them as Catholics and have influence than be on the outside' (Woolford 1975: 208; see also Griffin et al. 1979: 216-17). By this time, however, the Methodist and Seventh Day Adventist churches also supported secession. This consolidation of church support for Bougainvillean political initiatives helped to legitimise broader demands arising from the politicisation of Bougainvillean identity.

\section{The Impetus for Conflict}

While there was no planning for the major violent conflict that occurred from 1988, the elements of the situation just surveyed combined to contribute to a widespread sense of grievance amongst many Bougainvilleans. They resented a remote Port Moresby-based government for the imposition of the mine, for the limited share of mine revenue

15 Amongst the vocal clergy at the time was an American priest, Father Bob Wiley, then based at Tunuru, near Arawa. He was the parish priest at Panguna when the conflict began in 1988 and, in 1991, he claimed to have warned BCL 'big men' in the 1960s that it would be the then schoolchildren who would fight back later, when they grew up. He quoted one such schoolboy, Philip Takaung, who later told him that that the church personnel 'were the only ones who told us the truth ... no one could believe that the mountain was going to be removed' (Wiley 1991, cited in Laracy 2005: 132). In 2016, Philip Takaung was the vice-president of the Me'ekamui Government of Unity, based at Panguna. 
received by Bougainvilleans, for the influx of people from elsewhere in PNG, and for the problems that phenomenon was thought to be causing. The mine contributed to growing economic inequality, which was a particular source of tension in a situation of rapid population growth, where a high proportion of young adult males had little or no education and few opportunities for economic advancement, and where outsiders were seen as taking opportunities that should have been provided to Bougainvilleans.

Mine lease landowners-in particular younger adults-had even stronger feelings of grievance: about inadequate and unfairly distributed compensation, unfair access to mine employment and business opportunities, and environmental and related impacts. The rejection by younger adult leaders of key figures amongst their older compatriots resonated with concerns amongst many other Bougainvilleans about growing inequality and an emerging Bougainvillean elite. Grievances were articulated by leaders emerging from a small Catholic Churcheducated elite. Church sympathy for landowner grievances gave strong legitimacy to their cause. While the NSPG and Bougainvillean MPs in the PNG parliament were strongly sympathetic to Bougainvillean concerns, they were powerless to deliver change. This combination of circumstances provided fertile ground for the emergence of an alternative leadership voicing the grievances and demands of various elements of the Bougainvillean population.

\section{Conflict Origins: Groups, Concerns and Agendas ${ }^{16}$}

The sequence of events leading to mine closure in 1989 began with the theft of BCL explosives, damage to mine offices, and destruction of pylons carrying electricity to the mine from the coast. These were widely reported

16 The account in this part of the chapter draws on multiple sources, including many documents from the 1980s held in my files; personal communications over the past 20 years from key actors; and my observation of, or participation in, discussions amongst Bougainvillean leaders during preparations for, and conduct of, negotiations about the content and implementation of the BPA. Personal communications of particular importance came from Theodore Miriung (1994-96), Stephen Monei (1994-96), Joseph Kabui (1998-2008), Cornelius Besia (1999-2016), Jonathan Ngati (1999-2005), James Tanis (1999-2016), Damien Dameng (2002-05), Dennis Kuiai (2003-16), Albert Magoi (2011-12), William Mungta (2011), Ben Paula (2011-16), Lawrence Uakai (2011-14), Eddie Mohin (2013-16) and John Amuna (2015). 
as the actions of 'young generation' mine lease landowners-a view echoed in most subsequent accounts of the conflict origins. The young generation' mainly comprised adults under forty years of age, who were too young to have participated in the 1980 compensation negotiations.

Key young generation leaders included the subsequent Bougainville Revolutionary Army (BRA) leader, Francis Ona, and his cousin-sister, Perpetua Serero, respectively secretary and chair of the 'new PLA' (NPLA), which emerged from wider attempts to wrest PLA control from older generation leaders in August 1987. The NPLA's objectives are typically described as being to 'close the mine and arrest social disintegration' (Denoon 2000: 196). However, accounts emphasising the concerns and objectives of young generation leaders are almost invariably unbalanced. They ignore the extent to which these leaders represented the concerns of other members of their communities, including older generation leaders who had long been pressuring BCL about compensation issues. They also ignore the extent to which key motivating grievances arose from internal community conflicts only partially related to compensation-related issues, and significant linkages between young landowner leaders and the NSPG, the Bougainvillean MPs, and leaders of other Bougainvillean groups with a variety of grievances and objectives, only some of which were related to the mine.

\section{Mine Lease Landowners: 'Young' and 'Older' Generations}

As we have seen, Ona and Serero had a particular grievance originating in family disputes from long before mining started, whose significance is widely recognised in SML communities but otherwise little known. In 2014, a relative of Ona published an account of the issues involved (Roka 2014: 23-6), describing how Ona and his family (siblings and maternal first cousins) resented the unfair distribution of compensation by their uncle, Matthew Kove, a key landowner leader from Guava village. The source of the conflict was the control of land belonging to the lineage of Ona's grandfather's wife, Hali. Control of this land had passed through the matrilineal line to Hali's daughter from a relationship prior to her marriage to the grandfather. That daughter was Kove's mother. The result was that most of the descendants of Hali's marriage to the grandfather were largely excluded from decisions about their lineage land. They believed that this had enabled Kove to be designated as 'customary 
head' for five blocks, including one of the largest, in the SML. ${ }^{17}$ Roka describes how Kove and his immediate family became wealthy through the distribution of compensation at his discretion, ignoring Ona and his relatives. The latter pursued:

their education with what little they earned from the sale of vegetables. When they asked Matthew Kove for financial help, he was known to burn banknotes before their eyes (Roka 2014: 24-5).

Kove had influential roles in the PLA and RMTLTF, contributing to Ona's negative views of other leaders involved in control of those bodies. Roka describes how:

Serero, Ona and some other younger people began political sabotage to topple Matthew Kove and his cronies, who they claimed were corrupt and not landowner-oriented. Nearly all executives in the PLA had become rich men with high standards of living whilst the landowners felt they were in a backwater subjected to environmental pollution from the mine and harassment and exploitation by the rising population of Papua New Guineans brought to Bougainville as mine-workers. The Ona-Serero group's call for change around 1986-87 did not produce any results and its members rebelled ... in 1987 (Roka 2014: 25).

At the same time, Kove was a respected landowner leader and a signatory to the 1980 and 1986 compensation agreements between BCL and the PLA. His views on mining impacts and compensation-similar to those of the young generation leaders - were expressed to BCL in his capacity as a PLA executive member throughout the 1980s (Auna 1989: 10). In May 1987, together with other PLA leaders, including Ona (Griffin and Togolo 1997: 377), Kove attended a meeting with BCL's managing director at which he supported the 'Bougainville Initiative' adopted by John Momis. The speeches made at this meeting 'were very heated and contained threats to the effect that BCL could not expect to continue to conduct enormously profitable mining operations without a major redistribution of wealth amongst local ... landowners' (Auna 1989: 17).

Even in late 1988, well after the emergence of the NPLA, Kove appeared to support preparations for action against BCL when he attended a customary ceremony conducted by senior Nasioi men from the SML area to 'spiritually' prepare the small group that Ona was organising to begin such action (personal communication, Albert Magoi, July 2011). Feelings

17 I am grateful to Greg McNee for identifying the blocks in question. 
against Kove amongst his young relatives were so strong, however, that his was probably the first death arising from the conflict. He was killed by Ona's close relatives, in what was described as a 'traditional' manner, in January 1989 (Oliver 1991: 210).

The roles of Ona and Serero in the origins of the conflict have been variously characterised, but the most remarkable-and deeply misleadingdepiction is that of 'young activists at the vanguard of ... [an] anti-capitalist movement' challenging the 'old' PLA, and doing so 'to operationalise their [radical] social agenda' (Lasslett 2014: 49). There is in fact little credible evidence of their being so motivated, and much indicating that, in their cases, the impacts of common landowner grievances were dramatically intensified by personal grievances.

Ona certainly played a key leadership role in mobilising pressure against BCL, the PNG Government and the NSPG, being well equipped to do so because of the force of his personality and his own certainty about the rightness of whatever he did. Many close to him say that he was also remarkably stubborn and often closed to alternative views. When faced with criticism, he tended to blame others. He also drew inspiration from Catholicism. From at least late November 1988, when he took to the bush with a small support group to avoid capture by police mobile squads deployed in response to the damage then being done to BCL facilities, Ona focused heavily on prayer. His associates were required to join him, whether they were Catholic or not. He had a particular devotion to the Blessed Virgin Mary (Hermkens 2007), and told associates that he received guidance from both Mary and God.

The Ona-Serero group rebellion must also be seen in the context of an earlier and wider mobilisation of young landowners, which is evident in Joseph Kabui's early career. A young generation landowner from the upper part of the tailings lease, Kabui returned to Bougainville from the 'senior' Catholic seminary in Port Moresby in the late 1970s, and became an organiser of the Bougainville Mine Workers Union (BMWU). His relative, Michael Pariu, who played key roles in establishing and then leading both the PLA and the RMTLTF, was elected to the NSPG assembly in 1980 to represent the Ioro constituency, which included both SML and tailings lease areas. Growing dissatisfaction with the PLA and RMTLTF leadership on the part of young generation landowners led Kabui to campaign on their behalf and defeat Pariu in the 1984 election (personal communication, Joseph Kabui, October 1998). 
Kabui then supported Ona, Serero and others who (unsuccessfully) sought to extract more benefits for the younger generation from the PLA and the RMTLTF (Auna 1989: 18). Both Kabui and Momis supported them in the August 1987 PLA special general meeting of about 100 landowners that ousted the older leaders and elected a new executive, with Serero as chair and Ona as secretary. Members of the old executive rejected the outcome, insisting that they remained in control. To the frustration of the young leaders, BCL continued to recognise the old executive. Communication between the NPLA and BCL was initially limited to letters seeking company recognition, but in March 1988 it shifted to increasingly strident demands against BCL.

Despite the predominance of younger landowners, the NPLA did work closely with some key older generation leaders from both mine lease and adjacent areas. One of the most significant, Damien Dameng, was considerably older than most of the older PLA leaders. Though he came from an area just outside the mine lease boundaries, he had a significant following, held strong views on mining, and participated actively in most of the NPLA's written communications with BCL and actions against the company.

The concerns and demands of the NPLA were expressed from March to November 1988 in a variety of ways - through speeches made and a petition handed to BCL at a demonstration on 11 March 1988, through a series of letters to BCL, the NSPG and the PNG Government, and through demands made in at least nine meetings between those various entities. Copies of the petition and letters, and of minutes from several of the meetings, still exist, but difficulties arise in their selective use. First, NPLA demands varied over time, reflecting the concerns and goals of associated groups, not just those of young landowners. Second, 'outrageous demands are part and parcel of the Melanesian Way of doing politics' (Filer 1992: 441). Finally, many of Ona's letters were prepared by others whose particular concerns and personal styles could influence the content-a factor contributing to some of Ona's more radical assertions (personal communications, Lawrence Uakai and James Tanis, 2013).

As for their concerns, a useful summary appears in the minutes of a 26 May 1988 meeting between NSPG and PNG Government officials and NPLA representatives (NSPG 1988b; AGA 1989; Connell 1991). Six main categories were identified. Significantly, the first was 'environmental', involving loss of the previously 'happy life' of the 
people due to the destruction of land and environment. The second was 'relocation', involving inadequacy and lack of maintenance of the houses, which were by now becoming health risks, lack of housing for newly married couples, lack of garden land for relocated villages, inadequate septic tanks and water supplies, and lack of electric power. The third was 'business opportunities', involving BCL's use of mainly foreign contractors, and its involvement in non-mining businesses that unfairly competed with local businesses. The fourth was 'compensation', relating to outstanding payments for a particular village. The fifth was 'services', involving poor and unsafe roads for village access, and poor standards of health and education facilities in mine lease areas. And the sixth was 'inconvenience', involving the presence of squatter settlements in mine lease areas.

The demands made in this document included:

- dramatic increases in both compensation to mine lease landowners and mine revenue shares of landowners and NSPG;

- reimbursement to the NSPG of 50 per cent of mine revenue generated since mining began in 1972;

- priority in mine-related employment and contracts for landowners;

- much improved roads and services for landowners from both BCL and NSPG;

- much improved village relocation arrangements; and

- replacement of RMTLTF by NPLA as recipient of BCL SIC payments.

Both the concerns and the demands were broadly consistent with issues that had been raised by older generation PLA leaders in their 1980s engagement with BCL, including the demands made when Momis presented his Bougainville Initiative to BCL May 1987.

An earlier petition dated 11 March 1988, signed by Ona, Serero and Damien Damen (Dameng), included a demand for mine closure within 28 days (PLA 1988). It was in a letter to BCL dated 5 April 1988, signed by Ona and Serero, that a demand for payment of K10 billion (then equivalent to far more than US $\$ 10$ billion) was first made. In that letter, Ona and Serero stated that mining could continue if this demand were met, and if BCL:

- $\quad$ paid 50 per cent of its profits to landowners and NSPG; 
- consulted the NPLA before any mine expansion; and

- became a company owned by landowners and other Bougainvilleans within five years.

Informants close to Ona at the time advise that demands for mine closure were intended to pressure the PNG Government and BCL to negotiate new terms for mining. Permanent mine closure could not have been a serious demand when claims for additional payments, employment and contract preferences could only be met if mining continued. Nor can the K10 billion demand be seen as an indirect demand for mine closure. Then NSPG premier, Joseph Kabui, described this and related demands as 'ways my people are trying to express their fear and the feeling of total loss of their environment and lifestyle' (Kabui 1988, cited in Oliver 1998: 462-3). Moreover, by the time Ona started to demand secession from PNG, as in some of his statements in November 1988, he clearly envisaged the mine becoming independent Bougainville's main revenue source (Oliver 1991: 208) — a position he advanced in statements to BRA leaders as late as 1993 (personal communication, Eddie Mohin, July 2014).

Furthermore, the demands made by young landowners did not involve the repudiation of deals made previously by the older generation, as argued by Filer (1990). Rather, they involved a rejection of the unfair revenue distribution under the Bougainville Copper Agreement (BCA) and the 1980 and 1986 compensation agreements, and of the extent to which a small fraction of the older generation seemed to benefit from those arrangements. Although the old PLA leaders agreed that the arrangements were unfair, the NPLA leaders blamed the old leaders for both enriching themselves under these arrangements and failing to be sufficiently active in pursuit of change.

Even when Ona and his small support group went into the bush in late 1988, he remained open to negotiation. ${ }^{18}$ Early in December 1988, Momis and Kabui met Ona in his 'bush camp' on several occasions, seeking to persuade him to meet a new national government ministerial committee dealing with the emerging crisis. Ona agreed to a meeting in Guava on 8 December. At this stage, the mine had closed due to the destruction of a power supply pylon on 5 December. The tense meeting was attended by

18 This account draws on personal communications from Joseph Kabui (1998-2005) and John Momis (2014-15), copies of minutes and reports of the meeting held in my files, and a national newspaper article (Anon. 1988). 
four national government ministers, including Momis and Deputy Prime Minister Akoka Doi, representatives of the NSPG, including Kabui, and numerous landowners. Ona spoke of landowner concerns, insisting on renegotiation of the BCA and the withdrawal of police mobile squads. When the deputy prime minister agreed to both demands, Ona agreed to the mine reopening. Ona and other key figures proceeded to a hotel on the small island of Arovo, near Kieta, to sign the new agreement. On leaving that event, however, and contrary to the directions of the deputy prime minister, police arrested key landowner representatives. Ona felt betrayed by the national government, violent conflict intensified and negotiations ceased for some months.

In summary, there is no clear evidence that Ona was committed to either permanent mine closure or secession just before, or in the early stages of, the violence. Rather, the evidence suggests that he was mainly seeking to renegotiate the terms and conditions of mining. ${ }^{19}$ More generally, there is no evidence that Ona planned the violent conflict that actually occurred.

\section{Young Mineworkers}

The key roles of young Bougainvillean mineworkers (generally under thirty years of age) in the origins of the conflict have drawn little attention from commentators, but have long been acknowledged by other Bougainvillean actors. BRA leader Sam Kauona has described how Ona 'organised a core group comprising concerned Bougainvilleans ... working in the mine with him' (NZine 2000a). James Tanis, briefly employed by BCL during the university holidays in late 2008, reports that young mineworkers from all over Bougainville made 'bitter complaints that BCL was favouring the non-Bougainvilleans and giving limited opportunities to Bougainvilleans' (Tanis 2005: 467). Many of those involved later reported concerns that BCL unfairly ignored unemployed age-mates in their home areas.

The BMWU represented all of BCL's PNG citizen employees (Hess and Maidment 2014; Hess et al. 2016). As the majority were from elsewhere in PNG, young Bougainvillean mineworkers felt that the union could not

19 Writing early in 1990, anthropologist Gene Ogan reports the receipt of a letter from Bishop Singkai saying that Ona's main aim, even after the conflict developed, was 'to keep the Mine closed, thus punishing the Papua New Guinea Government that has taken so much from the landowners and the Province without putting anything back in return' (Ogan 1990: 39). 
represent their particular concerns, and they had little in common with most of the older Bougainvillean employees who accepted the company's policies too readily.

About 50 young men from all over Bougainville met irregularly for 18 months before the conflict began to discuss their grievances. A core group of seven or eight, led by Ona and later known as the BRA 'founders', met more regularly, gradually taking on planning and organisational roles. Members of the larger group made contributions to a fund intended to support action against BCL. Early in 1988, one was sent to Honiara with several thousand kina to buy weapons for use in a proposed rampage through the mine. Both he and the funds disappeared. Subsequently, a group of workers and landowners waited some days at Marau, on Bougainville's southwest coast. A submarine supposedly organised by a relative of Ona's, then studying overseas, was expected to deliver weapons and ammunition, but they never arrived. In both instances, the aim was to force negotiations with BCL and the government.

When these efforts failed, a core group of young landowners joined the 'founders' in organising the theft of BCL explosives. Power pylons were targeted because they were not protected by BCL security guards, and serious damage to even one of them would cause temporary mine closure. A series of joint operations destroyed a succession of pylons over several months from early December 1988. To plan and support those operations, and to avoid suspicion of their involvement, most of the 'founders' continued in employment with BCL until the mine closed in May 1989.

The young mineworkers sought temporary mine closure to force negotiations on new mining conditions that would be far more beneficial to Bougainvillean interests, including those of BCL employees. They saw no need to make public their particular concerns as they assumed that, once negotiations began, interests such as theirs could be joined with those of the young landowners at the negotiating table. Initially, they sought neither secession nor permanent mine closure. It was police mobile squad violence (from December 1988), followed by that of the PNG Defence Force (from April 1989), which provided the basis for leaders of other Bougainvillean groups to mobilise support for other goals, notably secession. 


\section{The Arawa Mungkas Association}

Although Ona was on the executive of this important Arawa-based organisation, its major focus was on the impacts of the influx into Bougainville of people from elsewhere in PNG and the limited minerelated opportunities for Bougainvilleans in general. The name, Mungkas Association, originated with Bougainvillean students at the University of PNG who met to discuss Bougainville's political future in the late 1960s (Griffin et al. 1979: 210-12). Various manifestations subsequently emerged, in Port Moresby and other urban centres, as well as in Bougainville, to address specific problems. The Arawa Mungkas Association, set up in 1987, comprised representatives of communities from many parts of Bougainville then resident in mine-related urban areas. During 1988, its members held public meetings and demonstrations to express grievances about squatter settlements.

The minutes of an executive meeting in held in Arawa on 24 March 1988, with Ona and Serero in attendance, provide insights into their concerns and demands. Squatters from elsewhere in PNG were said to be committing crimes, taking over customary land, running small businesses and taking jobs and business opportunities that should have been reserved for Bougainvilleans. The NSPG administrator, Peter Tsiamalili, reported on the Operation Mekim Save taskforce that had just been set up to respond to such problems. He counselled moderation and collaboration with the NSPG.

Some members wanted 'to take violent action now' (Mungkas 1988: 2), while others spoke of the need to save Bougainville from crime, or called for an end to the PNG plantation labour scheme, under which labourers were recruited from elsewhere in PNG, because 'it is the vehicle of death' (ibid.: 6). As an indication of the broad but unfocused sympathy amongst Bougainvilleans for secession from PNG, the minutes record unanimous agreement on two points: 'in view [of] all the suffering, misery and lose facing [sic] we have been made to bear', to 'put it in strongest terms to the Prov. [Provincial] and Nat. [National] Governments that North Solomons DEMANDS SUCCESSION [sic]'; but 'if they object to this demand', then the two governments must 'act immediately to remove all unemployed squatters from the whole of North Solomons', and the PNG Constitution must be amended to require employers to return workers to their place of origin at the end of their contracts. Furthermore: 
This meeting strongly felt that our inclusion with PNG is a direct route to Bville neutralisation. This is starting. This plan is not because of BCL, but for our own safety and wellbeing. (ibid.: 3)

Additional calls were made for BCL and the NSPG to remove outsiders; for 80 per cent of BCL employees to be Bougainvilleans; for BCL to terminate non-Bougainvillean contractors undertaking jobs that could be handled by Bougainvilleans; and for 'all tradestores [to] be returned to landowners' ${ }^{20}$ The minutes also record the presentation of a plan by 'landowners' (presumably the NPLA) that included 'mine shutdown', secession, and 'BCL demanded to pay K10 billion for the damage'. However, it is most unlikely that permanent closure was envisaged here, or that the Mungkas executive would have supported such a proposal, for the minutes also advocated pressure on BCL to preference Bougainvillean employees and contractors.

\section{'Pressure Groups' in Southwest Bougainville}

The Mungkas leaders had close links with the Bana Pressure Group, ${ }^{21}$ the Siwai Pressure Group and similar, though less well organised, groups from the Buin area. Bana and Siwai were relatively densely populated areas, with intensive cultivation of cash crops and associated land shortages, close to the mine, and hence experiencing some of its impacts. Little has ever been written about these groups and their roles in the conflict (but see Tanis 2005: 453-4, 463). Francis Ona received strong support from them, both before and after the conflict started.

These groups were mostly led by older men. Some held land adjacent to the tailings lease, receiving little or no compensation despite the impacts, leading to particular resentment of BCL. They were also concerned about the broader problem of environmental degradation, the lack of employment and business opportunities with the mine, and the number of non-Bougainvilleans now settling on their land or running small businesses nearby (Tanis 2005). Pressure group leaders thought that independence was the most realistic way of getting a fairer deal from BCL. They rejected the earlier generation of 'nationalist' Bougainville leadership

20 The mid-1988 NSPG report on law and order later assessed such proposals as 'impractical' (NSPG 1988a), only adding to Mungkas leadership frustration.

21 Bana is a term applied to the combined areas occupied by speakers of the Banoni, Baitsi and Nagovisi languages, being derived from the first two letters of the names of these languages. 
that had abandoned the secessionist cause in 1976. Their position was also a reaction to PNG's failure to agree to 1981 NSPG proposals for changing the BCA (Wesley-Smith 1992a).

As Bana Pressure Group chairman from mid-1988, James Singko expressed its position in ever more radical terms. From late 1988, he assisted Ona with funds raised from the sale of bananas and other crops from his plantation. He accompanied Ona into the bush in late 1988, bringing young men from his group, and soon becoming Ona's deputy in the BRA. He is also regarded as being the strongest proponent of secession, and central to that cause being agreed as a core goal of the rebellion at a major meeting at Sipuru, in central Bougainville, in late February 1989. In later tensions with Ona over the direction of the rebellion, Singko claimed the right to negotiate with the PNG Government on the issue since he was the sponsor of that particular aspect of their agenda (personal communication, James Tanis, July 2015).

\section{Marginalised Youth and Raskol Gangs}

Initial damage to BCL offices and power pylons in November 1988 led to indiscriminate violence by PNG police mobile squads against mine lease landowners. Young mineworker leaders then recruited disaffected agemates - many involved in criminal (raskol) gangs - to join what was soon being called the BRA, ${ }^{22}$ in the expectation that gang members would be more ready than others to meet the unexpected police violence with a violent response. This recruitment campaign helps to explain both the rapid expansion of Ona's support from early 1989, and some of the BRA's subsequent indiscipline.

Because the marginalised youth recruited in this way came from all over Bougainville, it is difficult to be specific about their goals. Information from some who undertook the recruiting indicates that few had political goals. Many were undisciplined and continued with their criminal activities (Oliver 1991: 214). Moreover, many were later involved in the chaotic situation that followed an agreement made on 2 March

22 In 1989, they were more frequently known as militants or 'Rambos'. Rambo was a character played by actor Sylvester Stallone in a popular 1982 movie, First Blood, which was very popular in Bougainville before and during the conflict. 
1990, under which PNG security forces withdrew from Bougainville by 16 March. On 8 March, Bishop Singkai expressed concern that the proposed withdrawal meant:

a power vacuum is being created which invites misguided youth to terrorise innocent persons. We believe that the BRA will influence the so-called 'Rambo Gangs' not to steal or destroy private property (Singkai 1990).

His hopes were not realised. Ona was concerned about the damage to BCL facilities and equipment because he envisaged an intact mine reopening as the main source of revenue for an independent Bougainville (personal communications, Joseph Kabui 2003, James Tanis 2005, Eddie Mohin 2015). In a radio broadcast on 18 March, he talked of receiving many complaints: 'Those you fought to protect now regard you as worse than the security forces ... a lot of you I don't consider as BRA'. He directed the return of vehicles and goods stolen 'against BRA law' and threatened that he could 'surrender now and everything will fall apart' (Oliver 1991: 237).

In a 2000 interview, former BRA leader Sam Kauona described the situation as follows:

Another problem arose from Bougainvilleans making claims to a lot of materials, including hundreds of vehicles abandoned by the mining company ... The soldiers in the BRA refused to listen to Sam. 'It was madness' said Sam. 'They didn't know how to drive the vehicles but they went from one to another-there were so many. There was virtually no control. They took all the money that was left in the drawers. Because of all the material goods Bougainvilleans started fighting against each other ... The problem became so complicated that it became impossible to address this internal instability' (NZine 2000b).

\section{Indigenous Political-Religious Movements}

The leaders of several highly autonomous local movements strongly supported the NPLA. Once regarded as 'cargo cults', they have more recently been described in Bougainville as 'indigenous political-religious movements' (BCC 2004: 32-3). The most significant was Me'ekamui Pontoku Onoring, led from the early 1960s by Damien Dameng, a man from Irang village, just a few kilometres southwest of Panguna (Oliver 1991: 180-1; Regan 2002; Tanis 2005: 461). 
Dameng sought the autonomy necessary for Bougainvillean communities to pursue their own 'development' paths based on their own choice to accept or reject elements of custom, Christianity, and other 'modern' institutions. He opposed mining as an uncontrollable force damaging culture and autonomy, and supported permanent mine closure. He had links with, and some influence over, similar movements elsewhere (BCC 2004: 32-3), most of which had supported secession in 1975, and did so again from early 1989.

Dameng associated closely with the NPLA. In March 1988, he signed the initial petition presented to BCL, along with Ona and Serero, being described in the document as 'Chairman of the Demonstration' (PLA 1988). He attended most of the meetings between the NPLA and representatives of BCL and the national and provincial governments between March and October 1988. He was the only person recorded as speaking for landowners at the 26 May meeting between NSPG and PNG Government officials (NSPG 1988b). And some of his supporters were amongst the young men who accompanied Ona into the bush late in 1988.

When police mobile squads began their active pursuit of Ona and his band, the latter moved southeast to the rugged and largely trackless Kongara Mountains. Most of the inhabitants were followers of the Methodist (now Uniting) church, but many also followed Dameng. Once in the area, Ona secured support from local clan leaders to recruit more young men to their group, and similar approaches were soon made to clan leaders and chiefs in other areas. ${ }^{23}$ This form of recruitment is the basis for recent assertions by some former combatant leaders of customary rights (to compensation) to be taken into account if the mine ever reopens.

\section{Church Blessings}

From an early stage there was a strong sense that the Catholic Church, in particular, supported the NPLA and, by extension, the BRA. From before the conflict, religious beliefs provided a source of inspiration to many of those involved. Church social justice teachings influenced many with Catholic seminary training, while other Catholics, including Ona, drew inspiration from a range of more basic Catholic teachings and practices.

23 In February 2016, families from the Mangkaa area in Kongara asked the Bougainville authorities for a goodwill payment for having provided food and shelter to Ona from August 1989. 
As violence spread from late 1988, Bishop Singkai and the Justice and Peace Committee of the Bougainville Diocese spoke publicly against PNG security force violence (Oliver 1991: 216, 219, 232-4; see also Griffin 1995). Singkai maintained close communication with Ona in his bush hide-out, amongst other things sending rosary beads to Ona and other members of his core group (personal communication, James Tanis, February 2016). Father Bob Wiley, a critic of the mine in 1966, was parish priest at Panguna in 1988, and was known as a BRA supporter (see Wiley 1992). ${ }^{24}$ Perceptions of church support were reinforced from mid-1990 when Bishop John Zale, head of the Uniting Church in Bougainville, joined Bishop Singkai as a member of the Bougainville Interim Government established by the BRA. ${ }^{25}$

Some Pentecostal Protestants also had their own biblical explanations for Bougainville's special place in God's plans. Such views were prevalent in the 1980s and continue to be widely discussed amongst Pentecostal Bougainvilleans in 2016. ${ }^{26}$ A variety of religious beliefs therefore contributed to the ideological emphasis on the primacy of Bougainvillean rights that emerged after 1989.

\section{Mainstream Politics}

While both the NSPG and the Bougainvillean representatives in PNG's national parliament were generally critical of BCL in the 1980s, they tended to support revision of the BCA rather than mine closure. John Momis attacked the unfairness of the BCA in a five-page letter known as 'The Bougainville Initiative' while he was campaigning in the 1987 national elections. When he presented it to BCL's managing director in May 1987, he was accompanied by Kove, Ona, and others who were later members of the NPLA (Auna 1989; Griffin and Togolo 1997: 377).

24 Early in 1989, he blessed BRA members before they went into operation and remonstrated strongly with one of Ona's local supporters who questioned whether this was appropriate priestly behaviour (personal communications, John Amuna and Wendelinus Bitanuma, 2015).

25 Both were members of the Bougainvillean delegation that negotiated a ceasefire with PNG Government representatives on the New Zealand naval ship Endeavour from 29 July 1990 (Oliver 1991: 248-53).

26 They were central to an 'awareness' package, regularly delivered from about 2010 by former BRA leader Sam Kauona, that concerned the 'stolen rights' to the gold of Bougainville. The theft was said to have begun with gold taken by the ships of the biblical King Solomon for the construction of the temple in Jerusalem. A 2010 paper by a former bible college lecturer close to the Me'ekamui leadership sets out similar views (Taruna 2010). 
This document (soon rejected by BCL) has been dismissed as an effort to prevent a reduction in the MA party's vote in the impending election (Griffin 1995: 16; Griffin and Togolo 1997: 377). BCL's former managing director later labelled it the 'major catalyst' of the conflict (Quodling 1991: 51-2), but Momis was acting in a way that more likely 'reflected rather than provoked the impatience of his electorate' (Filer 1992: 441). After all, he was close to the leaders of the groups discussed here, and his demands were similar to the 1981 NSPG proposals to the national government, made in advance of the failed review of the BCA, to increase royalties from 1.25 to 5 per cent (Wesley-Smith 1992b: 100), as well as to later positions taken by both the PLA and the NPLA.

Any confidence Ona and his supporters might have had in the NSPG and the MA members of parliament to advance NPLA concerns was undermined by internal MA conflict in 1988. Alexis Sarei, elected premier in 1984, unexpectedly resigned in 1987 (Oliver 1991: 194-5). The NSPG constitution required a province-wide 'presidential' by-election, but the MA-dominated NSPG assembly amended the constitution to enable election of a caretaker premier from among the sitting members. Joseph Kabui was the MA nominee who was elected. His NPLA associates saw this as a major advance for their cause, but the party's plan was that Kabui, who was seen as young and inexperienced, should merely 'keep the seat warm' for a more senior MA figure to be elected as premier in the 1988 provincial elections. To the anger of Momis, Kabui decided to run as a pro-MA candidate without MA endorsement. In a three-way contest he defeated both the former premier, Leo Hannett, and the MA candidate, Anthony Anugu. Momis and his party allies could not forgive Kabui, who in turn resented MA election campaign attacks on himself.

An unfortunate consequence of this was the much-reduced capacity of Bougainville's mainstream political leadership to cooperate as crisis became conflict. The standing of MA, and of Momis as the previously dominant figure in Bougainvillean politics, were both damaged: 'it was clear that people were no longer following party politics' (Tanis 2005: 469). The failure of the NSPG's 1988 Operation Mekim Save was also a grave disappointment to many people, and contributed to loss of faith in the NSPG's ability to protect Bougainvillean rights and interests as opposed to the constitutional rights of all PNG citizens (Tanis 2005: 466-7). That was undoubtedly a factor in the push for radical action amongst the coalition of groups identified here in the period from late October 1988 to February 1989. 
Kabui had a long history of links to Ona and his cause, and maintained these links after Ona went into the bush, but references to Kabui in Ona's frequent public statements in 1989 were increasingly dismissive. Other members of Kabui's government, while sympathetic to Ona, were soon deeply concerned about the escalating violence. They sought moderate solutions at the same time as Ona and the BRA became more radical in their demands. By the time of the March 1990 withdrawal of PNG security forces, the BRA felt that much of the NSPG had opposed them, and had little interest in sharing power with it.

\section{Linkages and Networks}

Extensive linkages existed between the leaders of most community groups involved in the origins of the conflict origins, and also between them, the state and the company. But, by late 1988, most of these groups were to varying degrees opposing both the national government and the NSPG, despite their links to individual MA members. Intergroup linkages meant that the NPLA, the Mungkas Association, the young mineworkers, the Bana and Siwai pressure groups, and Me'ekamui Pontoku Onoring operated as a loose coalition.

Bishop Singkai and several of his priests, notably Bob Wiley and Mark Roberts, also had close links with the NPLA and pressure group leaders. A significant proportion of the leaders of all groups came from the Catholic educated elite and so shared less formal links. Church support legitimised increasingly radical actions as being in the interests of Bougainville as a whole.

The core leadership of each group was small, and there were overlaps between them. Most of the key leaders were active MA members, which provided another set of linkages, yet each key one influenced and mobilised significant and to some extent distinct communities. Their influence was concentrated in central and southwest Bougainville, but for some it extended much further. Those stretching to almost all parts of Bougainville included the overarching church (especially Catholic) and MA networks, the Mungkas network (through Arawa-based communities from all over Bougainville), the indigenous politicalreligious movements', the disaffected young males, and the young men recruited through clan leaders. Hence, during 1988 and into 1989, the leadership reflected the concerns of, spoke to, and mobilised support from, a significant proportion of the whole population. Once violence 
on the part of (mostly non-Bougainvillean) police mobile squad members began in December 1988, it was a small step to build wider and more committed support networks, largely by mobilising people around ethnic divisions. Community concerns and demands rapidly moved beyond mine-related impacts, temporary mine closure, and the renegotiation of mining agreements. Support for secession was consolidated, and mining issues became secondary.

The groups increasingly worked together from late 1987 onwards. They played different roles, however, in the origins of the conflict. The NPLA, young landowners (some NPLA activists and others not) and young mineworkers initially took the lead. A few key members of Mungkas, the pressure groups and Me'ekamui Pontoku Onoring worked closely with the NPLA in the lead-up to the first violence against BCL in November 1988 , and then actively supported Ona as the conflict developed. Others only became actively engaged once police mobile squad violence started. Some marginalised youth and raskol gang members gravitated to Ona soon after the violence began, while others were actively recruited by young mineworkers from early 1989. As violence emerged, Mungkas and pressure group leaders mobilised support for Ona, some later becoming key BRA or Bougainville Interim Government leaders.

The group leaders had a range of attitudes to mining. Dameng wanted mining ended-a view attracting some, though not all, of his NPLA associates. Most of the young mineworkers, pressure group and Mungkas members sought much fairer conditions for mining. While almost all soon favoured secession, the pressure groups were initially most strongly committed to combining secession with continued mining, thus providing the revenue needed for independence.

From at least late 1987, Ona was a key link between the different groups. His own attitudes to future mining were ambivalent-sometimes probably for permanent mine closure, and sometimes more supportive of mining provided it was under radical new conditions. Undoubtedly, though, continued mining was key to the agenda of many in the wider coalition, and often for Ona's agenda as well. Needing to keep that coalition together, Ona could neither ignore the positions of other groups nor dominate their 
leaders, many of whom had the strength of personality to match him. Indeed, there were always some strong tensions in relationships between Ona and both Dameng and Singko. ${ }^{27}$

Of course, this coalition did not reflect the views of all Bougainvilleans. Other groups and leaders held different views on Panguna, and on Bougainville's future relations with PNG. However, part of the loose coalition's strength was that virtually all Bougainvilleans had sympathy for at least some aspects of their key concerns and demands.

It is most unlikely that any of the leaders of the various groups involved envisaged anything like the violent conflict that actually developed in 1989. Each wanted negotiations on a variety of related issues. Strong demands were initially directed towards negotiations over mining. Damage to BCL property occurred when frustration levels became high, and was intended to demonstrate the degree of frustration. The dangers of escalating violence involved in these actions were recognised by Ona and Singko when they took to the bush. But even when they had done so, in the early stages they were still prepared to negotiate. Undoubtedly, it was the deployment of the police riot squads, followed by the PNG Defence Force, and their often random and extreme violence, that transformed the issues and tactics, and led to active recruitment of young men willing to fight violence with violence.

\section{An Emergent Ideology 28}

The shared discussion of problems amongst the groups discussed here contributed to the beginnings of a shared ideology about the primacy of the rights of Bougainvilleans over those of outsiders. These were rights to mineral revenues and mine-related employment, contracts and businesses. Central was the idea that Bougainville's land, so central to clan identities, needed special protection from both mining and from people from elsewhere in PNG. Bougainvilleans deserved respect from outsiders, just as a Bougainvillean clan regarded as original to a particular area should be accorded respect by other clans, even those with some land rights in the area.

27 Some key figures found Ona frustrating to deal with, and one described it as like dealing with a maleo (an eel) (personal communication, Theodore Miriung, 1995).

28 The following analysis summarises information from personal communications by Theodore Miriung (1995-96), James Tanis (1998-2016), and Damien Dameng (2002). 
Emerging in the mid to late 1980s, these ideas were elaborated between 1990 and 1991. James Singko, by now Ona's deputy, took a lead role. Articulated in the Nasioi and Nagovisi languages, the ideas were seen as derived from both Bougainvillean culture and Christianity. Church support for Ona and the BRA added to their legitimacy. The emphasis was on the sacred nature of Bougainville and the traditions of its true people, and their concern about damage to both their land and traditions wrought by outsiders. The corollary was the duty of true Bougainvilleans to assert control over, or perhaps oust, outsiders causing harm, and to establish an original Bougainvillean government to protect the land, its people and their traditions.

The key principles were encapsulated in Nasioi words me'ekamui, sipungeta and osikaing. Me'ekamui means something akin to 'sacred land'. Just as the land of any particular Bougainvillean group is sacred to it, so the whole of Bougainville is sacred to all Bougainvilleans. Sipungeta literally means 'hearth'. In this context it meant something that was both 'original' and 'inventive', as well as being strengthened by fire, and therefore suggested the idea of control from a strong base. A government for the sacred land needed similar qualities, involving reliance on traditional strengths to respond to new challenges.

Osikaing means 'original inhabitants'. The original inhabitants of the sacred land had special duties towards that land, as well as corresponding rights. To be original, they must control what is theirs, especially their land. Outsiders entering it should respect osikaing ways. Osikaing contrasts with taboranku, meaning 'strangers' or 'aliens'. A stranger does not have the same rights as the original inhabitants. BCL, the national government and people from elsewhere in PNG were all strangers who had turned Bougainvillean osikaing into taboranku in their own land. Ousting outsiders and reasserting osikaing control would substitute social harmony for discord.

This ideology, emerging from debates preceding the conflict, and forged by the early heat of violence, continues to resonate in post-conflict debates about the future of LSM. 


\section{The Rectangular Model}

Discussion so far has focused mainly on the local community 'corner' in the rectangular model of stakeholder relationships (see Chapter 1, this volume), highlighting the complexity of these relationships. Though the 'fourth estate' was almost completely absent in 1988, brief comments can be made about the state and company 'corners' and the complex links between them and the community 'corner'.

The state 'corner' involved both the PNG Government and the NSPG. While the latter had no formal powers over mining, it was a significant factor in the local politics of LSM, with close links to the community sector. Although the national government was the regulator, it was largely seen as a remote presence, focused on exploiting Bougainville's mineral wealth to benefit the rest of PNG, and so mainly interested in the collection of mining revenues through dividends and taxation. As a result, state and company interests coincided. But key national government actors had deep links with the Bougainvillean community sector, especially John Momis and the MA's other Bougainvillean MPs.

As the only LSM entity in the province, BCL dominated the company 'corner', largely because of an official 'moratorium' on mining exploration or development in other parts of Bougainville that had been in place under PNG law from 1971. There were, however, many other mining-related companies providing services to BCL. The mining giant also had close links with local corporate entities that had close community links, as well as significant Bougainvillean entities like BDC and the RMTLTF. Some Bougainvilleans, like Severinus Ampaoi, were senior BCL employees, yet some employees of both BCL and its suppliers had close links to elements in the community 'corner'. In particular, several such employees provided active support to mine lease landowner groups during the critical period from 1987 to 1989 .

\section{Current Views on Resumption of Large-Scale Mining}

The current (2016) relationship between local-level politics and large-scale mining in Bougainville has both similarities and differences to that which existed between 1987 and 1989, especially with respect to the extent of community opposition to LSM. The current situation has of course been 
deeply influenced by dramatic changes arising from the conflict itself. Although the Panguna mine has been closed since 1989, the possibility of reopening it ensures that LSM is a factor in political relationships between PNG and Bougainville, and also within Bougainville.

The differences between the two situations include a major shift in the state's 'corner', largely resulting from the $2001 \mathrm{BPA}$, which made legislative authority over mining available to the ABG. There is also much greater complexity in each of the company, state and community 'corners' and in their mutual relationship, along with emergence of a new, multifaceted 'fourth estate' corner. Major differences arising from the complex postconflict situation include: the national government's much-reduced role in Bougainville as compared to 1988; the ABG's limited capacity and reach in a situation where several parallel 'governments' claim 'sovereignty' over all or part of the autonomous region; armed groups remaining a factor to contend with; and numerous fringe foreign mining interests seeking to play significant roles in alliance with different local factions. A major similarity is that multiple Bougainvillean groups with considerable autonomy from one another, aware that important decisions on the future of mining may be made in the foreseeable future, all seek to ensure that their voices are heard.

There is some continuity, too, in aspects of the issues being dealt with, and even in the identity of some key individuals involved in debate. ABG President John Momis, always a strident critic of BCL, who supported Francis Ona in 1987 and 1988, now supports the reopening of Panguna or possible development of a maximum of two other large-scale minesthat limit being set by the ABG's Bougainville Mining Act 2015. This does not involve a change in the president's long-term position, since he demands entirely new and fair mining conditions.

New actors in the political process include some of the leaders of nine new mine lease landowner associations established since 2011 to replace the PLA and NPLA, and others associated with the Me'ekamui Government of Unity. More familiar actors include figures formerly associated with both the PLA (Michael Pariu and Lawrence Daveona) and the NPLA (Wendelinus Bitanuma, John Amuna, Philip Miriori and Philip Takaung). For the most part, their positions are similar to that of Momis and the ABG. Nevertheless, the very different social, economic and political context of Bougainville in 2016 has resulted in dramatic changes in debates on the future of mining. 


\section{The State 'Corner'}

The state 'corner' now involves both the PNG Government and the ABG. Although the ABG became the sole regulator from 2014 under its own mining legislation, national government roles continue. Amongst other things, the PNG Government is the second largest shareholder in $\mathrm{BCL}$, and its legislation continues to cover some mining-related subjects, including occupational health and safety, land and environment. Tension between the two governments centres on the national government's efforts to remain involved in Bougainville mining matters by taking over Rio Tinto's equity in BCL.

Soon after it was established in mid-2005, the ABG began considering the possible resumption of LSM, which represented a significant shift from the positions of most Bougainvilleans early in the peace process, when resumption seemed unlikely (Regan 2014: 78). Concern about the revenue needed for either autonomy or independence led the first ABG president, Joseph Kabui, to examine this possibility from mid-2005, as did both his successors-James Tanis (2009-10) and John Momis (from 2010). The two main options under consideration have been the reopening of Panguna or the lifting of the 1971 'moratorium' on mineral exploration (preserved under the ABG's mining laws) with a view to possible developments elsewhere in Bougainville.

Kabui initially considered the first option, favouring potential developers other than BCL — initially a small Australian company called Ord River Resources Ltd. But intense pressure from former BRA commander Sam Kauona shifted Kabui and his cabinet to a second option, favouring a small Canadian company called Invincible Resources Ltd (IRL), which was established by Kauona's close associate Lindsay Semple, a dual Australian-Canadian citizen, solely for the purpose of mining investment in Bougainville. Semple raised funds from a number of high-risk investors and used the money for a number of 'development' projects directed towards gaining $A B G$ support for IRL to establish several new mines, smaller than Panguna, each in partnership with local landowners. The irresistible lure of significant revenue flows, ending the ABG's reliance on PNG Government grants, seemed to be underwritten by IRL's 2006 advance of a K20 million loan to the ABG to support 'capacity building'. In 2008, the $A B G$ signed an agreement with IRL whereby the latter would hold a 70 per cent stake in an entity called Bogenvil Resources 
Development Corporation (BRDC), supposedly established to implement a multisectoral Bougainville development plan using revenues generated by a virtual monopoly of mining activity beyond Panguna.

Controversies about IRL and BRDC centred on details of the K20 million loan repayment agreement, the failure of the 'development' projects, the opacity of the 30 per cent minority shareholding in BRDC, ${ }^{29}$ the near monopoly vested in IRL and the extent of indirect IRL control of the ABG. After Kabui died unexpectedly in June 2008, IRL and its ABG backers strove to ensure continued implementation of the development plan, but these efforts ended when Tanis became president in January 2009.

From early 2010, the ABG again examined the possibility of reopening Panguna. High commodity prices, proven reserves, and some existing mine-related infrastructure sustained optimism that reopening could occur within perhaps six years of negotiations commencing. By contrast, experience elsewhere in PNG showed that new mines take more than 15 years to get from exploration to operation. So, while open to other possibilities, the ABG under Tanis and Momis decided that Panguna offered the best prospect of significant revenues around the time of the referendum on independence that is due to be held in 2019. Paradoxically, reopening Panguna also offered the best prospect for meeting the expected high costs of remediating mine-related environmental damage and negative social impacts, such as those experienced by the relocated villages.

After Momis took office in June 2010, initial uncertainty about BCL as the preferred operator of a reopened Panguna mine was resolved in part because mine lease landowner community leaders argued in favour of BCL, preferring the 'devil they knew' to a 'new devil', mainly because BCL accepted some responsibility for the legacy issues. Uncertainty was also reduced as the result of a three-day ABG workshop on mining policy options, held in March 2011, that clarified the choice between the option of BCL reopening Panguna, an alternative developer doing so, and consideration of alternative prospects.

The ABG has consistently emphasised that no LSM will be permitted without landowner consent. Over three years from mid-2011, the ABG supported the establishment of nine independent associations to represent

29 Fifteen per cent was to be held by the ABG, 9 per cent by an 'ex-combatant's' company and 6 per cent by a company representing un-named Bougainvillean 'pioneer politicians'. The shareholders in these two companies have never been revealed. 
landowner communities impacted by the Panguna mine communities in considering possible resumption. Over 3,000 landowners voted for association executives at nine separate general meetings. ${ }^{30}$ The ABG has consulted the associations but has not sought to influence their positions on mining issues - indeed, there have been occasional tensions between the ABG and some association leaders. Five years on, in 2016, no decision had been made to even initiate negotiations with BCL or any other mining company about reopening Panguna.

Engagement with BCL has mainly been about steps preparatory to possible negotiation, inclusive of arrangements needed for a reconciliation process proposed by more than 50 mine lease landowner leaders who attended the first formal post-conflict meeting with the ABG and a senior BCL representative in July 2012. Extensive discussions have occurred within and between associations, and between them and the ABG, about possible conditions for reopening the mine, which reflects ideas about the primacy of Bougainvillean rights.

The $A B G$ also undertook extensive public consultations about the future of mining, which included consultations about its mining policy in 2010-11, about the future of Panguna and other possible LSM activities in 2013-14, ${ }^{31}$ and about its draft mining legislation in 2014-15. In the absence of opinion polling, it is difficult to be certain as to whether there has been a preponderance of views one way or another. Nevertheless, those involved in organising the consultation reported broad community support for resumption of mining. That is consistent with regular feedback to the ABG from the nine Panguna landowner association executives, as well as from the elected $A B G$ members from their own constituencies, including the mine lease areas.

From about 2014, the ABG began seriously examining options other than reopening Panguna. The reasons for this included:

- falling commodity prices, which made it less likely that the reopening could be financed (at an estimated cost of US $\$ 6-8$ billion);

- growing realisation of the extent to which negative sovereign risk assessment could make financing even more difficult;

30 This contrasts with roughly 100 attending the 1987 meeting that elected the NPLA executive.

31 This involved five regional public forums, and separate forums for women leaders and ex-combatants. 
- the high expectations of mine lease landowners, former combatants, and others about compensation, not just for mining impacts but also a range of conflict impacts; and

- the increasingly disruptive activities of small foreign companies linked to different Bougainville factions.

In taking over full regulatory responsibility for mining, the $A B G$ established its own mining department in 2007, negotiated transfer of national government powers (2006-08) and developed its own mining policy (2009-14). It developed its own mining law in two main stages. The first was the Bougainville Mining (Transitional Arrangements) Act, proposed in 2012 and enacted in 2014 (Regan 2014: 87-91). This first law was based on PNG's existing Mining Act, but with significant changes to meet Bougainville's needs. These included:

- vesting both the ownership of minerals and powerful veto rights over exploration in the owners of customary land;

- divesting BCL of its mining tenements, leaving only an exploration licence over the former SML; and

- imposing a strict prohibition on the operation of more than two very large mines (like Panguna) at one time.

The second stage involved passage of the Bougainville Mining Act in March 2015. It was the product of the policy development process initiated in 2009, incorporated many of the initiatives included in the 2014 Act, and extended landowner rights to include the power of veto over mining development tenements, as well as exploration licences.

While reluctantly accepting the validity of this $A B G$ legislation, the national government was attempting (from 2013) to purchase Rio Tinto's 53.8 per cent equity in BCL, thus raising its own stake in the company to 72.8 per cent. Opposing this move, the ABG argued that:

- PNG majority ownership of the mine at the heart of the conflict was unacceptable in Bougainville;

- the PNG Government was seeking to control Panguna despite the transfer of mining powers to the ABG; and

- PNG would gain significant control of the Bougainville economy, which would be a sensitive issue in the lead-up to the referendum. 
The ABG demanded that, if Rio Tinto divested, then its equity should be 'gifted' to the ABG and the landowners, and it should provide significant additional funding to meet corporate responsibilities for mine legacy issues, including extensive environmental, social and human rights impacts, especially for the thousands of relocated people who were now living in appalling conditions (Momis 2015). These issues remain unresolved at the time of writing.

\section{The Community 'Corner'}

Just as in 1988-89, this part of the matrix of stakeholder relationships extends well beyond the immediate vicinity of Panguna. Since the 1960s, the significant social and economic impacts of the mine have ensured that most Bougainvilleans have felt that they have some stake in Panguna's mineral resources. These feelings grew far stronger after the conflict, in which all communities shed blood, many at Ona's explicit request. Under customary principles applicable in most Bougainvillean cultures, if blood is shed when supporting landowners in land-related conflict, the clan whose blood is shed gains some rights over the land in question. Such principles are referred to widely in public discussions about Panguna.

The three main groups of former combatants are a significant new addition to the 'community corner'. ${ }^{32}$ Theirs have become increasingly prominent voices in public debates since Momis was elected as ABG president in 2010, partly because of suspicions of his PNG Government links. Two of the most significant voices are those of the former BRA leaders Sam Kauona and Ishmael Toroama. Kauona presents as a strident critic of BCL, opposed to the reopening of Panguna and the ABG's mining policies, despite his own close association since 2004 with foreign corporate mining interests, most notably IRL. For Toroama, a key issue in Panguna-related debate is recognition of the rights of former combatants on the basis of blood shed during the conflict.

Despite the major logistical and financial difficulties involved, the ABG has made extensive efforts to consult widely about the future of LSM, not just with mine lease landowner communities, but amongst Bougainvilleans more generally. Elected executives of the nine landowner

32 The three groups are the original BRA, the Bougainville Resistance Forces that opposed them, and the Me'ekamui Defence Force, most of whose members defected from the BRA to remain with Ona when he refused to support the peace process in 1998. 
associations, representing what could now be as many as 15,000 people in the mine lease areas, have consulted widely with their own communities as well as with the ABG. Consistent with the outcomes of the ABG's wider process of community consultation, they report broad community support for mining resumption, but only under fair conditions, including redress for past injustices.

\section{The Company 'Corner'}

In June 2016, Rio Tinto announced a plan to transfer its 53.8 per cent stake in BCL to an 'independent trustee' that would be jointly owned by the PNG Government and the ABG. Under the terms of this arrangement, Rio aimed to transfer 36.4 per cent of its equity in BCL to the ABG, and 17.4 per cent to the PNG Government. This meant that both would hold an equal proportion (36.4 per cent) of the shares in BCL, since the PNG Government already held 19 per cent. This announcement aroused a storm of protest from nearly all of the Bougainvillean actors mentioned in this chapter, most of whom demanded that the PNG Government should transfer the 17.4 per cent to the ABG so that it would become the majority shareholder (Anon. 2016a). This move was opposed by PNG Prime Minister Peter O’Neill, who announced instead that the 17.4 per cent would be transferred to a trust for the benefit of all Bougainvilleans, including the Panguna landowners (Anon. 2016b, 2016c). This left the PNG Government with its original 19 per cent stake, the ABG with 36.4 per cent, the trust with 17.4 per cent and several thousand small shareholders with a little over 27 per cent.

An account of the details and ramifications of these developments, and the new political process engendered by this turn of events, is beyond the scope of this chapter, but it has not so far led to any significant change in the prospects of reopening the Panguna mine. What it might have done is to limit the scope for continued interference by other foreign companies in the prospective development of LSM projects in Bougainville.

In 1988 there was a small local corporate sector linked to the mine, notably the BDC and the RMTLTF, but both of these entities ceased to operate soon after the conflict began, and it is still unclear what happened to their funds and some of their other assets. By 2016, however, several other sets of corporate interests had emerged, with strong linkages to different Bougainvillean groups. 
As previously mentioned, former BRA leader Sam Kauona, supported by a small group of other former combatants, has had close links to dual Australian-Canadian citizen Lindsay Semple since 2004-05. Semple and Kauona have been financially supported by a series of at least three main external investors: the Canadian company IRL from 2004 to 2010; another Canadian company, Morumbi Resources, from 2010 to 2013 (Regan 2014: 86-9); and from 2015, New York investment firm Kuhns Brothers. They lost most of their influence over the ABG when Joseph Kabui died in 2008, and their cause then seemed to be lost in 2010 when the investors in IRL lost faith in Semple. However, they soon re-entered the field with Morumbi, seeking exclusive rights to exploration and development in prospective areas through agreements made between Morumbi subsidiaries and small groups of landowners, which they unsuccessfully sought to persuade the ABG to recognise. After Canadian police visited Bougainville in late 2013 to investigate the activities of both IRL and Morumbi, the latter cut its ties to Semple. Since Kuhns Brothers became involved, their activities have included the establishment of a small gold-buying and refining operation, the creation of an investment fund called Bougainville Fund Management LLC, ${ }^{33}$ and various proposals for funding development projects outside the mining sector in what appears to be an approach similar to that attempted by IRL.

Since Ona's death in July 2005, one of the two main sets of self-proclaimed successors to his leadership of the 'Me'ekamui' groups claiming to be the legitimate Bougainville government (as alternatives to the $A B G$ ) has been the Panguna-based Me' ekamui Government of Unity (MGU). The MGU has also had extensive involvement with a succession of small foreign companies. The first was Australian registered company Tall J Foundation Pty Ltd, involving a group of American citizens who attempted mechanised extraction of gold from the Panguna riverine tailings in 2008. It was followed by Cefeida SA, a company established in 2009 by former Tall J investors, Stewart Sytner and Thomas Megas, to attract investment funds by claiming 'that they possessed exclusive rights to develop and mine in [Bougainville] ... and that such rights "were extremely valuable and rare for outsiders". ${ }^{34}$ Next was a Canadian company, Transpacific Ventures Ltd, also linked to Sytner. It produced an information memorandum for prospective investors in July 2013, claiming an agreement with the MGU

33 See www.secinfo.com/d1yT3c.we.htm (viewed 24 April 2016).

34 Amiron Development Corporation v Sytner [2013] E.D. New York 12-CV-3036, 29 March. 
'on an exclusive basis for 20 years renewable, to advise the customary landowners (the Me'ekamui) in developing their natural resources sector' under a new mining law 'expected to transfer all land and mineral rights on the island of Bougainville and its territorial waters to the Sovereign Me'ekamui Tribal Government (the Me'ekamui)' (Transpacific Ventures 2013: 2). In 2014, Transpacific was succeeded by Australian company, United Resources Management Pacific, which was succeeded in 2016 by another Australian company, Central Exploration, both of which were introduced to the MGU by an Australian, Ian Renzie Duncan, who was previously involved in Transpacific Ventures. The companies involved, from about 2012 until at least the end of 2015, paid monthly 'salaries' to senior MGU members.

These are just a few of the small corporate entities that have sought access to Bougainville's mineral resources since the ABG began considering the possibility of renewed LSM. Many have sought to advance their interests with no reference to the ABG. Rather, they have used links with the leaders of local factions (some armed) or have engaged in direct dealings with small landowner groups from prospective areas. The need to control such entities provided a major impetus for the ABG to develop its initial mining legislation in 2012 .

\section{The 'Fourth Estate'}

From 1989, the Bougainville conflict attracted considerable international attention, particularly in Australia. Several NGOs and other groups supported the BRA, or Bougainvilleans suffering the impacts of the PNG Government's air and sea blockade of Bougainville imposed from mid-1990. These supporters included existing organisations and new ones established for the purpose, such as the Independent Bougainville Information Service, Australian Humanitarian Aid for Bougainville and Bougainville Freedom Movement (BFM).

Since the conflict ended, a few additional groups and some individuals have become involved, particularly with the emergence of debate on the future of LSM. They have included 'mediators' offering services to the $\mathrm{ABG}$, as well as some journalists, lawyers, advisers or consultants mainly seeking to advise or influence various Bougainvillean groups-especially Panguna lease landowner associations. 
Since the ABG began developing its mining legislation in mid-2012, a concerted campaign against its mining policy has been mounted by a network of fourth estate actors whose central point appears to be Australian 'activist' academic, Kristian Lasslett. He is involved with the International State Crime Initiative, whose website includes material purporting to document the responsibility of Rio Tinto and BCL for the conflict and its impacts, and demanding that they be brought to account. ${ }^{35}$ This view is advanced in Lasslett's own publications (e.g. Lasslett 2014) and in other publications in which he acknowledges a central role (e.g. Jubilee 2014).

The main PNG node in this network is the Bismarck Ramu Group, which operates two blogs that feature stories about mining on Bougainville'PNGexposed', ${ }^{36}$ which is intended to expose political corruption, and 'Papua New Guinea Mine Watch', which was established to campaign against environmental damage by the Ramu nickel mine in PNG's Madang Province, but has since expanded its remit to other mining projects. ${ }^{37}$ Both blogs regularly publish strong attacks on the $A B G$, some under Lasslett's name, but many anonymous, though very much in Lasslett's style. According to Lasslett, the Bismarck Ramu Group is 'one of Papua New Guinea's unsung treasures, and their support over the years has been truly amazing' (Lasslett 2014: $\mathrm{x}$ ).

The Australian branch of the network includes Jubilee Australia, an NGO that has published two reports highly critical of the ABG's mining policy and legislation (Jubilee 2014, 2015). The research for its 2014 report was overseen by Lasslett, who has had close links with Jubilee since his student days. The two Bougainvilleans who undertook the research were close associates of Lasslett, and are known to share his views on BCL and Rio Tinto.

The Australian branch also includes a few MPs from the Greens and Labour parties. Greens Party senator Lee Rhiannon has spoken at the launches of the Jubilee reports, and has regularly asked questions of the Australian Department of Foreign Affairs and Trade in Senate Estimates Hearings about alleged Australian Government influence on ABG mining policy. Antony Loewenstein, an Australian activist journalist and author,

35 See: www.statecrime.org/testimonyproject/bougainville.

36 For stories about Bougainville, see: pngexposed.wordpress.com/tag/bougainville/.

37 For stories about Bougainville, see: ramumine.wordpress.com/tag/bougainville/. 
has written articles critical of $A B G$ mining policy, and covers such issues in his book on 'vulture capitalism' (Loewenstein 2013). Loewenstein acknowledges the support and assistance of Lasslett in his writings on Bougainville.

Finally, the Australian node includes the BFM, the last of the 'support groups' from the 1990s that still has a public voice. It regularly attacks the ABG on the PNG Mine Watch blog, as well as in other outlets such as 'New Dawn on Bougainville', in pieces by written by Vikki John. Lasslett acknowledges the 'encouragement and guidance from activists and advocates involved in the Bougainville anti-war and independence movements' that he received while doing his $\mathrm{PhD}$ research on 'statecorporate decisions and motivations that underpinned the crimes on Bougainville' (from 1988-89), including support from key BFM figures, Vikki John amongst them (Lasslett 2014: ix).

This 'fourth estate' network does have some links in Bougainvillean communities, but mainly with a few people who share the views of other network members. Curiously, Lasslett's connections include a key personal staff member of Jimmy Miringtoro, one of Bougainville's MPs in PNG's national parliament, who, despite being a strident critic of the ABG's mining policies, has his own interests in the selection of companies that might redevelop the Panguna mine.

All the members of this network advance strident claims about what they believe to be the general opposition to mining on the part of either the people of Bougainville in general, or of mine lease communities in particular. The evidence offered in support of these claims is weak or flawed. For example, the basis for Jubilee's 2014 claims that 'the mine affected communities' are 'opposed to any discussion of the mine's reopening' (Jubilee 2014: 46) was a set of 'semi-structured' interviews with just 65 individuals selected by a 'snowballing' technique, plus a single focus group discussion with 17 males in a village just outside the mine lease area who 'refused to be interviewed separately, instead stating that they preferred to reach a consensus ... and then present one common position for each question' (ibid.: 49). In a situation where there are perhaps 15,000 people in former mine lease area communities, where it is well established that a large (but unknown) proportion support the resumption of mining, subject to strict conditions, the most likely 
explanation for the unanimous opposition reported from this supposed 'sample' is the so-called 'snowballing' technique adopted and supervised by persons who are themselves deeply opposed to resumption.

None of the members of this supposed 'civil society' network has ever communicated with the ABG or the landowner associations about the issues on which they so regularly make public comment. They do not countenance the possibility that, in considering resumption, the ABG and the landowner associations find themselves with very limited options as they seek realistic means of not only providing a secure basis for Bougainville's autonomy or possible independence, but also creating new livelihoods for the former mine lease communities.

The sustained attacks by members of the network on President Momis, the $\mathrm{ABG}$, advisers to the $\mathrm{ABG}^{38}$ and the Australian Government (for funding such advice) are based on the assumption, unsupported by credible evidence, of a strong consensus against the reopening of Panguna or any other form of LSM. They make such assumptions in the process of projecting their own theories, ideologies or needs onto Bougainville, convinced that they are finding or providing the supporting evidence. None has the motivation to understand the facts and the complexity of Bougainville, either in 2016 or in the period from 1987 to 1989.

Their activities have had little impact in Bougainville or on Bougainvilleans, other than providing support to groups seeking control over the region's mineral resources in partnership with foreign investors other than Rio Tinto. Their analysis has, however, influenced the positions of some donor countries, and those of some international NGOs involved in Bougainville. In these ways, they contribute to tensions, divisions and conflicts of which they have little understanding.

\section{Conclusion}

Returning to the central issues identified in the introduction to this chapter, I address four main questions:

- Are the origins of the conflict to be found primarily in the concerns of young mine lease landowners committed to permanent mine closure?

38 As an adviser to the ABG, funded by Australia at the ABG's request, I have been the subject of sustained criticism and attack from these quarters. 
- What was the relationship between Francis Ona, or the NPLA, and the other Bougainvillean groups involved in the origins of the conflict?

- Was there generalised opposition to mining amongst these other groups in the period 1987-89?

- Is there generalised Bougainvillean opposition to the resumption of LSM in 2016?

Having addressed the questions, I shall consider the whether the rectangular model of stakeholder relationships advocated in the introduction to this book effectively captures the complexity of stakeholder relationships in the Bougainville case.

The evidence presented here establishes that the conflict did not originate mainly in the concerns of young mine lease landowners to put an end to LSM. The dominant public voices of Ona and the NPLA have confused the picture, especially where there has been selective reading of their public statements. The local-level politics of LSM was never confined to the mine leases or adjacent areas directly affected by mining. The peculiar features of its island geography, history and political economy mean that Bougainville constitutes a quite distinct political arena within PNG. It is an arena within which LSM is regarded as having had various impacts on all Bougainvilleans, not just mine lease landowners, generating a range of different concerns and demands. There is no evidence of either generalised resistance to LSM per se, by either Bougainvilleans in general or local landowner communities in particular, or of general support for permanent mine closure from either group. Indeed, it is not possible to find a consistent position on the future of mining even in the various documents stating the concerns and demands of the NPLA. There is clear evidence, however, of general (and resounding) rejection by both landowners and the other groups discussed here of the unfairness of the $\mathrm{BCA}$ as the basis for mining.

Francis Ona was not a class hero in the vanguard of an anti-capitalist movement. Rather, he was a key actor whose own interests, concerns and networks placed him at a critically important intersection of wider interests, concerns and influences that included Christian and customary values. He arrived at that intersection, and was inspired to take on a leadership role, not only because of the unfairness of his own situation as a young adult landowner, gravely exacerbated by a bitter family dispute, but also because of his own personality. What evidence we have of his motivations and roles points to the importance of individual agency in 
the relationship between LSM and local-level politics, while the evidence of the roles of other key figures in the various groups considered here indicates the difficulties of mapping the influence of multiple individual motivations.

The linkages between the various groups involved in the origins of the conflict were developing from at least as early as 1987 and, as a result, by early 1988 Ona increasingly saw himself, and was seen by the leaders of other groups, as the key spokesperson for a coalition of interests. While some of his statements could be interpreted as expressions of a desire for permanent mine closure, many were clearly more directed to pressuring BCL to meet specific demands for a fairer mining dispensation which could only be met if mining continued. Those demands reflected the views of the loose coalition with which Ona and the NPLA were working.

The existence of that coalition in 1988 helps to explain some key aspects of the early stages of the conflict that have not previously been well understood. One is the rapid mobilisation of mainly young men in all parts of Bougainville from early 1989. Another is the fact that violence was not directed only against BCL and the PNG security forces, but also against other Bougainvilleans - some wealthy, or educated, or in middle-ranking to senior government or company jobs. The generalised resentment of marginalised young males was the key here. Further, the chaotic situation that emerged after the PNG security forces withdrew in March 1990 was largely due to the BRA's recruitment of criminal gang members and disaffected youth.

With a few notable exceptions, such as Damien Dameng's group, there is no evidence that the other Bougainvillean groups involved in the origins of the conflict were seeking permanent mine closure. In this respect, there are similarities between the situation that existed in 1987-89 and that which exists in 2016. Undoubtedly, in 2016 some people oppose the resumption of LSM under any circumstances. But many other opinions on mining also exist. In the absence of either representative opinion polling or rigorous research, it is difficult for even the $\mathrm{ABG}$, despite its extensive public consultation, to be certain about the preponderance of views on the future of LSM, either on the part of mine lease landowners or Bougainvilleans more generally. It is clearly a mistake to take 'noise' created by fourth estate actors, especially those in the 'Lasslett network', as in any way accurately representing a majority position. 
Just as in 1988, there is a multiplicity of positions on this issue. That should be no surprise, given the history of mining, the expectations of mine lease landowners, the ABG's revenue needs, the referendum timetable, and the multiple agendas of foreign actors who have developed links with Bougainvillean groups in the hope of economic advantage from either the reopening of Panguna or the exploration of other prospects.

Again, as in 1988, some Bougainvilleans oppose any form of LSM, including some in the former BCL lease areas strongly opposed to Panguna reopening. However, there is certainly some evidence that major voices in the debate are more concerned with the conditions under which a limited resumption of mining might be permitted - a situation that is also similar to 1988. Many groups and leaders, sometimes claimed by outside commentators to be 'anti-mining' (Anon. 2015), are in fact strong supporters of mining but have their own reasons for attacking the ABG on the issues involved (Regan 2014: 85-93).

To some extent, what appears to be happening in the 'community corner' involves multiple interest groups staking out positions in advance of any decision on the future of mining. Without the existence of political parties conducting policy debate, Bougainvilleans generally expect decisions on major issues to be made by some form of consensus. To influence such decisions, voices in favour of particular positions jostle to be heard. The situation points to difficulties in the operation of systems of elected representative government in a cultural context such as that found in Bougainville.

The ideology of primacy of Bougainvillean rights remains a lasting legacy of the Bougainville conflict, heavily influencing much of the Bougainville Mining Act 2015, including provisions on the ownership of minerals by owners of customary land, the distribution of preferences for employment and business opportunities, and the resettlement of communities impacted by mining. These provisions are remarkably similar to the NPLA demands of 1988 .

The same principles are also brought to the fore in ABG discussions with the nine landowner associations about the possible future of Panguna. The kinds of landowner benefit packages negotiated for mining projects elsewhere in PNG are unlikely to be sufficient to gain landowner 
community support for future LSM in Bougainville. Whether any responsible investor will be able to envisage a profitable enterprise in such circumstances has yet to be tested.

As to the reasons for the hitherto very incomplete understanding of the origins of the conflict, analysis of the composition and roles of the network of Bougainvillean groups that were involved underlines the complexity of the 'community corner' in 1988. It also illuminates some of the main reasons for the difficulties involved in gaining accurate understandings of the groups involved and their relationships one with another. These relationships were opaque even to most Bougainvilleans at the time. In large part this was because just one group — the NPLA—was making most or the public statements. Most of the others had no reason to draw attention to themselves. Indeed, some had good reason to avoid scrutiny.

The mainly oral traditions of Bougainvillean communities are also a factor here, because they help to explain why so few of those involved produced written records of what they were doing. After 1988, the situation changed very quickly, as the key issues no longer involved the future of mining. Even so, few-if any-of those previously involved now had any reason to record what they had done or why. Furthermore, there was a long period from the early 1990s when many had good reasons not to discuss their involvement - at least until immunity from prosecution for 'crisisrelated' offences was provided under the 2001 BPA.

As to whether the rectangular model of stakeholder relationships effectively captures the complexity of the relationships on Bougainville, evidence from 1988-89 emphasises the danger in seeing one or more communities or voices as constituting a single community 'stakeholder'. The many groups then involved had multiple, and often quite distinct, concerns and agendas, and complex relationships one with another, as well as with actors in the state and company 'corners' at that time. The image of a rectangle, with distinct sets of stakeholders in their separate 'corners', may well be useful as a classificatory device, but, in itself, it does not help us to understand the complexities of relationships within or between the actors in each category. Those relationships are perhaps more akin to complex webs made up of interpersonal and intergroup linkages. 


\section{References}

AGA (Applied Geology Associates Ltd), 1989. Environmental, SocioEconomic, Public Health Review of Bougainville Copper Mine, Panguna. Wellington: AGA.

Anis, T., E. Makis, T. Miriung and E. Ogan, 1976. 'Towards a New Politics? The Elections in Bougainville.' In D. Stone (ed.), Prelude to Self-Government: Electoral Politics in Papua New Guinea. Canberra: The Australian National University, Research School of Pacific Studies.

Anon., 1988. 'Rebels Agree to End the Sabotage' Post-Courier, 10 December.

__ 2015. 'Momis Loses the Vote in Panguna Heartland.' PNG Mine Watch Blogpost, 4 June. Viewed 12 October 2016 at: ramumine. wordpress.com/2015/06/04/momis-loses-the-vote-in-pangunaheartland/

__, 2016a. 'Outrage over BCL Shares.' Post-Courier, 1 July.

__, 2016b. 'B'ville Majority Owner of Copper Ltd.' The National, 18 August.

__, 2016c. 'PM Adament [sic] on Shares.' Post-Courier, 19 August.

Auna, J., 1989. 'Affidavit of Joseph Lawrence Auna.' Filed in the Supreme Court of Victoria in CL220 of 1989, Bougainville Copper Limited $v$ Metals and Minerals Insurance Pte Ltd and Ors.

Ballard, C. and G. Banks, 2003. 'Resource Wars: The Anthropology of Mining.' Annual Review of Anthropology 32: 287-313. doi.org/ 10.1146/annurev.anthro.32.061002.093116

BCC (Bougainville Constitutional Commission), 2004. 'Report of the Bougainville Constitutional Commission: Report on the Third and Final Draft of the Bougainville Constitution.' Arawa and Buka: BCC.

Bedford, R. and A. Mamak, 1977. Compensating for Development: The Bougainville Case. Christchurch: University of Canterbury, Department of Geography (Bougainville Special Publication 2). 
Boege, V., 1999. 'Mining, Environmental Degradation and War: The Bougainville Case.' In M. Suliman (ed.), Ecology, Politics and Violent Conflict. London: Zed Books.

Braithwaite, J., H. Charlesworth, P. Reddy and L. Dunn, 2010. Reconciliation and Architectures of Commitment: Sequencing Peace in Bougainville. Canberra: ANU E Press.

Brown, W., 2014. 'Telefomin and Panguna: A Kiap's View.' In C. Spark, S. Spark and C. Twomey (eds), Australians in Papua New Guinea 1960-1975. St Lucia: University of Queensland Press.

Connell, J., 1978. Taim Bilong Mani: The Evolution of Agriculture in a Solomon Island Society. Canberra: The Australian National University, Development Studies Centre (Monograph 12).

_ 1988. 'Temporary Townsfolk? Siwai Migrants in Urban Papua New Guinea.' Pacific Studies 11(3): 77-100.

—_ 1990. 'Panguna Mine Impact (1).' In P. Polomka (ed.), Bougainville: Perspectives on a Crisis. Canberra: The Australian National University, Strategic and Defence Studies Centre (Canberra Papers on Strategy and Defence 66).

_ 1991. 'Competition and Conflict: The Bougainville Copper Mine, Papua New Guinea.' In J. Connell and R. Howitt (eds), Mining and Indigenous Peoples in Australasia. Melbourne: Oxford University Press.

_ 1992. "'Logic is a Capitalist Cover-up": Compensation and Crisis in Bougainville, Papua New Guinea'. In S. Henningham and R.J. May (eds), Resources Development and Politics in the Pacific Islands. Bathurst (NSW): Crawford House Press.

Denoon, D., 2000. Getting under the Skin: The Bougainville Copper Agreement and the Creation of the Panguna Mine. Melbourne: Melbourne University Press.

Dorney, S., 1990. Papua New Guinea: People, Politics and History since 1975. Sydney: Random House.

Downs, I., 1980. The Australian Trusteeship: Papua New Guinea 1945-75. Canberra: Australian Government Publishing Service. 
Filer, C., 1990. 'The Bougainville Rebellion, the Mining Industry and the Process of Social Disintegration in Papua New Guinea.' In R.J. May and M. Spriggs (eds), The Bougainville Crisis. Bathurst (NSW): Crawford House Press. doi.org/10.1080/03149099009508487

_- 1992. Review of P. Quodling's Bougainville: The Mine and the People. Contemporary Pacific 4: 440-442.

__ 2005. 'The Role of Land-owning Communities in Papua New Guinea’s Mineral Policy Framework.' In E. Bastida, T. Wälde and J. Warden-Fernández (eds), International and Comparative Mineral Law and Policy: Trends and Prospects. The Hague: Kluwer Law International.

Fingleton, W., 1970. 'Bougainville: A Chronicle of Just Grievances.' New Guinea Quarterly 5(2): 13-20.

Ghai, Y. and A. Regan, 1992. The Law, Politics and Administration of Decentralisation in Papua New Guinea. Port Moresby: National Research Institute (Monograph 30).

—_, 2000. 'Bougainville and the Dialectics of Ethnicity, Autonomy and Separation.' In Y. Ghai (ed.), Autonomy and Ethnicity: Negotiating Competing Claims in Multi-Ethnic States. Cambridge: Cambridge University Press.

__, 2006. 'Unitary State, Devolution, Autonomy, Secession: Dialectics of State Building and Nation Building in Bougainville, Papua New Guinea.' The Round Table 95: 386, 589-608. doi.org/ $10.1080 / 00358530600931178$

Gillespie, W.R., 2009. Running With Rebels: Behind the Lies in Bougainville's Hidden War. Port Kembla (NSW): Ginibi Productions.

Griffin, J., 1995. Bougainville: A Challenge for the Churches. North Sydney: Catholic Commission for Justice and Peace.

Griffin, J., H. Nelson and S. Firth, 1979. Papua New Guinea: A Political History. Richmond (VA): Heinemann Educational Australia.

Griffin, J. and M. Togolo, 1997. 'North Solomons Province, 1974-2000.' In R. May and A. Regan (eds), Political Decentralisation in a New State: The Experience of Provincial Government in Papua New Guinea. Bathurst (NSW): Crawford House Press. 
Hermkens, A., 2007. 'Religion in War and Peace: Unravelling Mary's Intervention in the Bougainville Crisis.' Culture and Religion 8: 271-289. doi.org/10.1080/14755610701652111

Hess, M. and E. Maidment, 2014. 'Industrial Conflict in Paradise: Making the Bougainville Copper Construction Agreement 1970.' Economic and Labour Relations Review 25: 271-289. doi.org/ $10.1177 / 1035304614533625$

Hess, M., E. Maidment, and G. Keimelo, 2016. 'Establishing the Bougainville Mineworkers' Union, 1969-1976.' Journal of Pacific History 51: 21-42. doi.org/10.1080/00223344.2015.1095274

Jubilee, 2014. Voices of Bougainville: Nikana Kangsi, Nikana Dong Damana (Our Land, Our Future). Sydney: Jubilee Australia.

— 2015. The Devil in the Detail. Analysis of the Bougainville Mining Act 2015. Sydney: Jubilee Australia.

Kenema, S., 2010. 'An Analysis of Post-Conflict Explanations of Indigenous Dissent Relating to the Bougainville Copper Mining Conflict, Papua New Guinea.' Intersections 1.2 and 2.1, April.

Laracy, H., 1999. 'Maine, Massachusetts, and the Marists: American Catholic Missionaries in the South Pacific.' Catholic Historical Record 85: 566-590. doi.org/10.1353/cat.1999.0139

—, 2005. "Imperium in Imperio"? The Catholic Church in Bougainville.' In A. Regan and H. Griffin (eds), Bougainville Before the Conflict. Canberra: Pandanus Books.

Lasslett, K., 2014. State Crime on the Margins of Empire: Rio Tinto, the War on Bougainville and Resistance to Mining. London: Pluto Press.

Loewenstein, A., 2013. Profits of Doom: How Vulture Capitalism is Swallowing the World. Melbourne: Melbourne University Press.

Lummani, J., 2005. 'Post-1960s Cocoa and Copra Production in Bougainville.' In A. Regan and H. Griffin (eds), Bougainville Before the Conflict. Canberra: Pandanus Books. 
MacWilliam, S., 2005. 'Post-War Reconstruction in Bougainville: Plantations, Smallholders and Indigenous Capital.' In A. Regan and H. Griffin (eds), Bougainville Before the Conflict. Canberra: Pandanus Books.

__, 2013. Securing Village Life: Development in Late Colonial Papua New Guinea. Canberra: ANU E Press.

Mamak, A., R.D. Bedford, L. Hannett and M. Havini, 1974. Bougainvillean Nationalism: Aspects of Unity and Discord. Christchurch: University of Canterbury, Department of Geography (Bougainville Special Publication 1).

McNee, G., 2015. 'Social Mapping and Landowner Identification Desktop Study.' In Final Report Prepared for Joint Panguna Negotiations Coordination Committee. Perth: Social Sustainability Services Pty Ltd.

Mitchell, D.D., 1976. Land and Agriculture in Nagovisi, Papua New Guinea. Boroko: Institute of Applied Social and Economic Research (Monograph 3).

——, 1982. 'Frozen Assets in Nagovisi.' Oceania 53: 57-65.

Momis, J., 2015. 'ABG Position on Panguna Mine Future, and PNG Proposals to Purchase Rio Tinto Shares in BCL.' Statement by President John L. Momis to the Bougainville House of Representatives, 22 December.

Mungkas, 1988. 'Mungkas Ass. Meet 2/88 Prov. Commerc. Conf. Room 24/3/88, 1800.' Handwritten meeting minutes.

Nash, J. and E. Ogan, 1990. 'The Red and the Black: Bougainvillean Perceptions of other Papua New Guineans.' Pacific Studies 13(2): 1-17.

Nelson, H., 2005. 'Bougainville in World War II.' In A. Regan and H. Griffin (eds), Bougainville Before the Conflict. Canberra: Pandanus Books.

NSPG (North Solomons Provincial Government), 1986a. 'North Solomons Provincial Policy for Youth in Their Communities.' Arawa: NSPG Division of Community Affairs (unpublished report). 
— 1986b. 'Department of North Solomons: Information Paper No.3 July 1986.' In A. Sarei (ed.), Department of North Solomons, Information Papers: Provincial Task Force; Provincial Disaster Relief Programme; Squatter Settlements. Arawa: Department of North Solomons (unpublished report).

_ 1988a. 'North Solomons Provincial Government 1988 Law and Order Report.' Arawa: NSPG Planning Office (unpublished report).

_ 1988b. 'Special Meeting between the National Government and North Solomons Provincial Government Held at the Provincial Assembly Hall on the 26th May 1988.' Unpublished meeting minutes.

NZine, 2000a. 'Conflict in Bougainville-Part 2: Interview with Sam Kauona Sirivi.' Blogpost by 'Dorothy', 23 June. Viewed 16 March 2017 at: www.nzine.co.nz/features/bville2.html

—, 2000b. 'Conflict in Bougainville-Part 3: Successes of the Bougainville Revolutionary Army.' Blogpost by 'Dorothy', 23 June. Viewed 16 March 2017 at: www.nzine.co.nz/features/bville3.html

Ogan, E., 1965. 'An Election in Bougainville.' Ethnology 14: 397-407. doi.org/10.2307/3772789

_ _ 1971a. 'Charisma and Race.' In A. Epstein, R. Parker and M. Reay, (eds), The Politics of Dependence: Papua New Guinea 1968. Canberra: Australian National University Press.

— 1971b. 'Nasioi Land Tenure: An Extended Case Study.' Oceania 42: 81-93. doi.org/10.1002/j.1834-4461.1971.tb00306.x

- 1972. Business and Cargo: Socio-Economic Change among the Nasioi of Bougainville. Port Moresby and Canberra: The Australian National University, New Guinea Research Unit (Bulletin 44).

— 1990. 'Perspectives on a Crisis (5).' In P. Polomka (ed.), Bougainville: Perspectives on a Crisis. Canberra: The Australian National University, Strategic and Defence Studies Centre (Canberra Papers on Strategy and Defence 66).

— 2005 . 'An Introduction to Bougainville Cultures.' In A. Regan and H. Griffin (eds), Bougainville Before the Conflict. Canberra: Pandanus Books. 
Okole, H., 1990. 'The Politics of the Panguna Landowners' Organization.' In R. May and M. Spriggs (eds), The Bougainville Crisis. Bathurst (NSW): Crawford House Press.

Oliver, D., 1991. Black Islanders: A Personal Perspective of Bougainville 1937-1991. Melbourne: Hyland House.

Oliver, M., 1998. 'July-December 1988.' In C. Moore and M. Kooyam (eds), A Papua New Guinea Political Chronicle 1967-1991. Bathurst (NSW): Crawford House Publishing.

PLA (Panguna Landowners Association), 1988. '11 th March Mine Closer [sic] Demonstration-1988: The Main Topics to be Highlighted in the Speech by Members of Panguna Landowners Association.' Unpublished document.

Quodling, P., 1991. Bougainville: The Mine and the People. Sydney: Centre for Independent Studies (Pacific Paper 3).

Regan A., 1998. 'Causes and Course of the Bougainville Conflict.' Journal of Pacific History 33: 269-285. doi.org/10.1080/00223349808572878

—_, 2002. 'Bougainville: Beyond Survival.' Cultural Survival26: 20-24.

__, 2005a. 'Identities among Bougainvilleans.' In A. Regan and H. Griffin (eds), Bougainville Before the Conflict. Canberra: Pandanus Books.

__, 2005b. 'A Note for Readers.' In A. Regan and H. Griffin (eds), Bougainville Before the Conflict. Canberra: Pandanus Books.

__, 2011. Light Intervention: Lessons from Bougainville. Washington (DC): United States Institute of Peace Press.

__ 2014. 'Bougainville: Large-Scale Mining and the Risks of Conflict Recurrence.' Security Challenges 10(2): 71-96.

Rimoldi, M. and E. Rimoldi, 1992. Hahalis and the Labour of Love: A Social Movement on Buka Island. Oxford: Berg.

Roka, L., 2014. 'Bougainville Manifesto.' Hervey Bay: Puk Puk Publications.

Singkai, G., 1990. 'Diocese of Bougainville, March 08, 1990: Press Release.' Unpublished document. 
Tanis, J., 2005. 'Nagovisi Villages as a Window on Bougainville in 1988.' In A. Regan and H. Griffin (eds), Bougainville Before the Conflict. Canberra: Pandanus Books.

Taruna, J., 2010. 'A Bougainville Israeli Link: A Completion of the New Covenant Signed by the President, Dr. John Momis on the [sic] October 28th 2010.' Unpublished paper.

Thompson, H. and S. MacWilliam, 1992. The Political Economy of Papua New Guinea: Critical Essays. Manila: Journal of Contemporary Asia Press.

Transpacific Ventures, 2013. 'Updated Information Memorandum to Subscribe for $8,000,000$ Shares at $A \$ 0.10$ per Share in Transpacific Ventures Limited.' Unpublished document.

Tryon, D., 2005. 'The Languages of Bougainville.' In A. Regan and H. Griffin (eds), Bougainville Before the Conflict. Canberra: Pandanus Books.

Turner, M., 1990. Papua New Guinea: The Challenge of Independence. Ringwood (VA): Penguin Books.

Tyler, M., 1988. 'Nutrition \& Subsistence Food Production Project, Siwai North Solomons Province, September 1985 - June 1988.' Arawa: North Solomons Provincial Government (unpublished report).

Vernon, D., 2005. 'The Panguna Mine.' In A. Regan and H. Griffin (eds), Bougainville Before the Conflict. Canberra: Pandanus Books.

Wesley-Smith, T., 1992a. 'The Non-Review of the Bougainville Copper Agreement.' In M. Spriggs and D. Denoon (eds), The Bougainville Crisis: 1991 Update. Canberra: The Australian National University, Research School of Pacific Studies, Department of Political and Social Change (Monograph 16).

— $1992 \mathrm{~b}$. 'Development and Crisis in Bougainville: A Bibliographic Essay.' Contemporary Pacific 4: 407-432.

Wiley, B., 1992. 'Bougainville: A Matter of Attitude.' Contemporary Pacific 4: 376-378.

Woolford, D., 1975. Papua New Guinea: Initiation and Independence. St Lucia: University of Queensland Press. 
This text is taken from Large-scale Mines and Local-level Politics: Between New Caledonia and Papua New Guinea, edited by Colin Filer and Pierre-Yves Le Meur, published 2017 by ANU Press, The Australian National University, Canberra, Australia. 